\title{
Parameters affecting the fundamental period of infilled RC frame structures
}

\author{
Panagiotis G. Asteris ${ }^{* 1}$, Constantinos C. Repapis ${ }^{2}$, Athanasios K. Tsaris ${ }^{1}$, \\ Fabio Di Trapani ${ }^{3}$ and Liborio Cavaleri ${ }^{3}$ \\ ${ }^{1}$ Computational Mechanics Laboratory, School of Pedagogical and Technological Education, \\ Heraklion, GR 14121, Athens, Greece \\ ${ }^{2}$ Department of Civil Engineering, Piraeus University of Applied Sciences, 250 Thivon and Petrou Ralli Str., \\ Aigaleo 122 44, Athens, Greece \\ ${ }^{3}$ Department of Civil, Environmental, Aerospace and Materials Engineering (DICAM), University of Palermo, \\ Viale delle Scienze, 90128, Palermo, Italy
}

(Received June 8, 2015, Revised July 30, 2015, Accepted July 31, 2015)

\begin{abstract}
Despite the fact that the fundamental period appears to be one of the most critical parameters for the seismic design of structures according to the modal superposition method, the so far available in the literature proposals for its estimation are often conflicting with each other making their use uncertain. Furthermore, the majority of these proposals do not take into account the presence of infills walls into the structure despite the fact that infill walls increase the stiffness and mass of structure leading to significant changes in the fundamental period numerical value. Toward this end, this paper presents a detailed and indepth analytical investigation on the parameters that affect the fundamental period of reinforce concrete structure. The calculated values of the fundamental period are compared against those obtained from the seismic code and equations proposed by various researchers in the literature. From the analysis of the results it has been found that the number of storeys, the span length, the stiffness of the infill wall panels, the location of the soft storeys and the soil type are crucial parameters that influence the fundamental period of RC buildings.
\end{abstract}

Keywords: fundamental period; infilled frames; masonry; modal analysis; reinforced concrete buildings

\section{Introduction}

The ability to estimate the fundamental period of vibration of structures by means of simple models/expressions offers a major input for the design of buildings and/or the assessment of their seismic performance. Although the use of methods for the evaluation of seismic forces by response spectra is valid only in the case of strictly regular buildings (in plan and elevation) subjected to linear static analysis, their implementation offers an immediate comparison with the extent of seismic demand and is actually quite useful in practice (e.g., for preliminary assessments

*Corresponding author, Associate Professor, E-mail: panagiotisasteris@ gmail.com 
of structural elements dimensions or determinations of base shear demand). Such evaluation methods are largely used for the assessment of seismic vulnerability at the territorial scale both for pre and post-earthquake scenarios. It has been in fact demonstrated that the fundamental period of constructions is strictly correlated to structural damage (Massumi and Moshtagh 2010, Eleftheriadou and Karabinis 2013, Ditommaso et al. 2013) and therefore possible reliable estimations may prove useful to local civil protection bodies for the definition risk maps and planning of intervention strategies. The estimation of the fundamental period is furthermore required when implementing earthquake loss assessment methodologies.

The fundamental period of vibration depends on the distribution of the mass and the stiffness of the structure. For this reason, the presence of non-structural elements, which may produce a variation of these properties, should be carefully considered.

It is noteworthy to mention that the determination of the fundamental period by different methods and techniques, ranging from the simplest to the more complex, is still affected by a certain degree of uncertainty. The majority concern the fact that technical code formulas, as well as those available in the literature, when comparable, lead (for the same structures) to scattered results having differences greater than $200 \%$. On the other hand the use of advanced computational models of RC buildings generally leads to more reliable values of the fundamental period.

The most reasonable cause for such predictive discrepancies can be attributed to the complex interaction arising between primary structures and masonry infill panels. It is in fact well known that in the presence of lateral actions masonry infills partially detach from the surrounding frame, remaining in contact with this only in correspondence of two opposite corners. A significant bracing action, affecting both the strength and stiffness originates by this mechanism, as demonstrated by a large number of experimental investigations (Smith 1966, Page et al. 1985, Mehrabi et al. 1966, Cavaleri et al. 2005, Misir et al. 2012, Arslan and Durmus 2014, Al-Nimry et al. 2014, Cavaleri and Trapani 2014) and analytical-numerical studies (Dhanasekar and Page 1986, Chrysostomou 1991, Saneinejad and Hobbs 1995, Chrysostomou et al. 2002, Asteris 2003, 2005, 2008, Cavaleri and Papia 2003, 2014, Moghaddam 2004, Hora 2006, Kakaletsis and Karayannis 2009, Agrawal and Hora 2012, Erdolen and Dorana 2012, Kose and Kayadelen 2013, Al-Nimry et al. 2014, Campione et al. 2014, Cavaleri and Tripani 2015). However, despite several modelling strategies available in the literature, going from pinned equivalent struts macromodeling to $\mathrm{FE}$ micromodeling (Moghaddam and Dowling 1987, Papia et al. 2003, Asteris et al. 2011, 2013, Chrysostomou and Asteris 2012), masonry infills are generally not accounted in models because of the large amount of uncertainties arising during their structural identification. In these cases the determination of dynamic properties results are rather unreliable in seismic performance assessments. At the same time, the direct formulas for the determination of the fundamental period of vibration, generally depend on a few parameters (height of the building, number of stories, base length) and may or may not consider the presence of infills (implicitly or explicitly). For this reason, the outcomes of the calculations are scattered. Furthermore, the determination of seismic actions necessarily reflects these uncertainties; thus the predictive error affecting the structural response is added to an imprecise evaluation of seismic demand, generating further uncertainties on the overall reliability of the assessment procedures.

Besides the infill-frame interaction and the height of the construction, several other parameters affect the fundamental period of vibration, such as the irregularity in plan and elevation, the number of storeys, the number of spans (and respective dimensions), the presence of openings within infills and the rigidity of storeys. For this reason a reliable estimation of the fundamental period by simple and at the same time reliable expressions is not easy and still constitutes a task of 
major interest.

Each of the above mentioned parameters have an influence on the actual value of the fundamental period of a construction. However, it is reasonable to think that some of them have more relevance than others. Based on this, the paper presents an extensive and in depth sensitivity analysis on the parameters affecting the fundamental period, such as the number of spans, the span length, the position of soft storeys, the stiffness of masonry infills and their percentage of openings and the soil type.

\section{Estimation of fundamental period for $\mathrm{RC}$ buildings with and without infills}

\subsection{Building design codes expressions}

Worldwide codes provide simple empirical formulas for the estimation of the fundamental period of vibration (T) of constructions. In most of the cases are such expressions are simply related to the overall height of the buildings. Among these, a large number of technical codes refer to the following

$$
T=C_{\mathrm{t}} \cdot H^{3 / 4}
$$

In Eq. (1) $H$ is the total height of the building (in meters) and $C_{\mathrm{t}}$ is a numerical coefficient depending on the structural typology. Such relationship originates by the application of Rayleigh's method by assuming a linear distribution of lateral forces and a constant distribution of mass and stiffness. The above expression was adopted for the first time in 1978 by ATC3-06 (1978) for RC framed structures. The determination of the coefficient $C_{\mathrm{t}}$ was carried out based on the measurements of the periods of buildings during the San Fernando earthquake (1971). A regression analysis of the experimental data led to a value of 0.075 for $C_{\mathrm{t}}$. The same expression has been adopted by Eurocode 8 (2004) and Uniform Building Code (UBC 1997).

Based on EC8, Italian technical code (D.M. LL. PP. 2008) also adopts Eq. (1), confirming the value of $C_{\mathrm{t}}=0.075$ for reinforced concrete constructions and 0.085 for steel, while a value 0.05 is suggested for all other structural typologies.

In a similar way other codes report the same formula presenting small variations of the coefficient $C_{\mathrm{t}}$. Among these, the New Zealand Seismic Code (NZSEE 2006) which states a value of 0.09 for reinforced concrete frames, 0.14 for structural steel and 0.06 for other types of structures, and the Israeli Seismic Code (SI-413 1994) which provides the values 0.073, 0.085 and 0.049 for concrete, steel and other structural typologies respectively.

An update of the previous expression, calibrated on the observations of Californian earthquakes, can be found in the Federal Emergency Management Agency (FEMA-450 2003). The fundamental period is calculated as follows

$$
T=C_{\mathrm{r}} H_{\mathrm{n}}^{\mathrm{x}}
$$

$H_{\mathrm{n}}$ being overall height (in meters) and $C_{\mathrm{r}}$ and $x$ take the values 0.0466 and 0.9 respectively.

Other codes provide expressions of the fundamental period related to the number of stories of buildings rather than their height. It is the case of Canadian National Building Code (NBC 1995) which for a RC building of $N$ stories above the ground states the following relationship

$$
T=0.1 N
$$


In a similar way Costa Rican Code (1986) states

$$
T=0.08 N
$$

A comparison between the results obtainable by the application of the previously discussed relationships is reported in Fig. 1, where the Canadian and Costa Rican formulas have been also included considering an average storey height of $3.3 \mathrm{~m}$. From the comparison of the curves, it appears clear that, despite a similar trend, the estimation of the fundamental period by the different expressions brings to values whose difference is even in the order of $50-100 \%$. It can be moreover observed that among the presented curves the standard EC8 equation settles approximately in average position.

The above reported code expressions refer to reinforced concrete structures, without specifying the degree of stiffening action considered for the infills or shear walls. Such relationships can be in fact used indifferently for bare and infilled frame structures. Conversely other code formulas present specific coefficients or implementations in order to account for the reduction of the period because of the presence of infills or shear walls. The Jordanian National Building Code (2005) and Israeli (SI-413 1994) still adopt Eq. (1) for the evaluation of the fundamental period of vibration but simply suggest a properly reduced value of $C_{\mathrm{t}}$ for infilled RC frame buildings, equal to 0.04 and 0.049 respectively.

Another group of seismic codes (Indian IS-1893 2002, Egyptian 1988, Venezuelan 1988, French AFPS-90 1990 and Algerian 1988) propose the use of an expression which, besides the height of the building, takes into consideration the total base dimension, $d$ (in meters), of the building

$$
T=0.09 \frac{H}{\sqrt{\mathrm{d}}}
$$

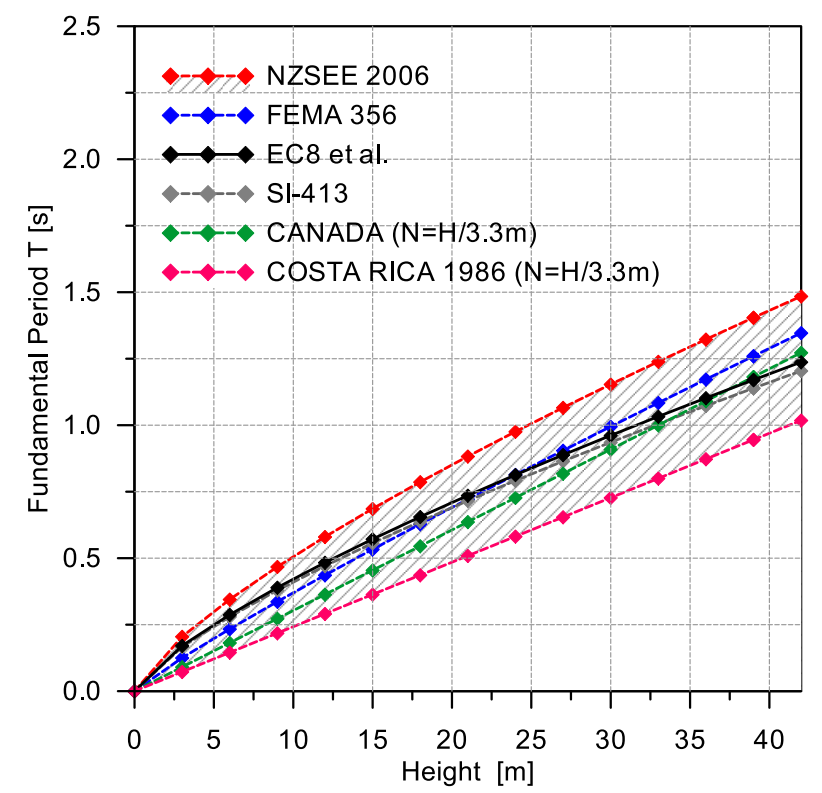

Fig. 1 Results of comparison of code expressions for the estimation of fundamental period of RC frame structures 
The Algerian Seismic Code (1988) specifies moreover to determine the period as the minimum between Eq. (5) and Eq. (1) with $C_{\mathrm{t}}=0.05$.

In an older version of the Columbian code (NSR-84 1984) an expression (Eq. (6)) to calculate an equivalent $d$ length as function of the amount of infills can be found

$$
d=d_{s, \max } \sum_{1}^{N_{s}}\left(\frac{d_{s}}{d_{s, \max }}\right)^{2}
$$

In Eq. (6) $d_{s}$ is the length of each wall, $d_{s, \text { max }}$ the length of the largest wall and $N_{s}$ the number of walls.

An adaption of Eq. (5), accounting for the influence of shear walls on the fundamental period of the RC buildings can be found in the Greek Seismic Code (EAK 2003) as shown in Eq. (7)

$$
T=0.09 \frac{H}{\sqrt{d}} \sqrt{\frac{H}{H+\rho d}}
$$

where the $\rho$ is the ratio of the areas of shear wall sections along the direction of analysis to the total area of walls and columns.

In order to account for the presence of infills the Eurocode 8 (2004) still refers to the heightrelated expression (Eq. (1)), but provides in such case a specific expression for the calculation of the coefficient $C_{t}$ that is defined as follows

$$
C_{\mathrm{t}}=\frac{0.075}{\sqrt{A_{\mathrm{c}}}} \quad \text { and } \quad A_{\mathrm{C}}=\sum A_{\mathrm{i}}\left(0.2+\frac{l_{\mathrm{wi}}}{H}\right)^{2}
$$

In Eq. (8) $A_{\mathrm{c}}$ is a term representing the combined effective area of the masonry infill in the first storey, $A_{\mathrm{i}}$ is the generic area of the wall $i$ in the direction considered in the first storey and $l_{\mathrm{wi}}$ its length. An alternative expression for the calculation of $A_{\mathrm{c}}$ is provided in the latest Colombian code (NSR-98) (Eq. (9))

$$
A_{c}=\sum A_{i}\left(0.02+\left(\frac{l_{w i}}{H}\right)^{2}\right)
$$

An analogous approach is followed by Philippine Code (NSCP 1992). The expression for the calculation of $C_{\mathrm{t}}$ and $A_{\mathrm{c}}$ are below reported

$$
C_{t}=\frac{0.03048}{\sqrt{A_{c}}} ; \text { and } A_{c}=\sum A_{i}\left(0.2+\left(\frac{l_{u i}}{H}\right)^{2}\right)
$$

Parameters $A_{\mathrm{c}}$ and $d$ appearing in Eqs. (1) and (5) influence the period the more the building is high. The diagrams reported in Fig. 2 show their impact on the fundamental period.

In Fig. 3 a comparison between the different code expressions for the specific evaluation of the fundamental period of masonry infilled RC buildings is presented. For Eq. (5) two values of d (20 $\mathrm{m}$ and $40 \mathrm{~m})$ are used and for Eq. (1) $\left(\mathrm{C}_{\mathrm{t}}\right.$ depending on Eqs. (8) and (9)) three values of $\mathrm{A}_{\mathrm{c}}{ }^{0.5}(1.3$, 1.8 and 2.5) are used.

Despite the uniform tendency to provide lower values for the fundamental period, with respect to the previously reported curves, the results appear also in this case scattered and present the same 
level of discrepancy. The EC8 standard Eq. (1) is plotted as reference in Fig. 3.

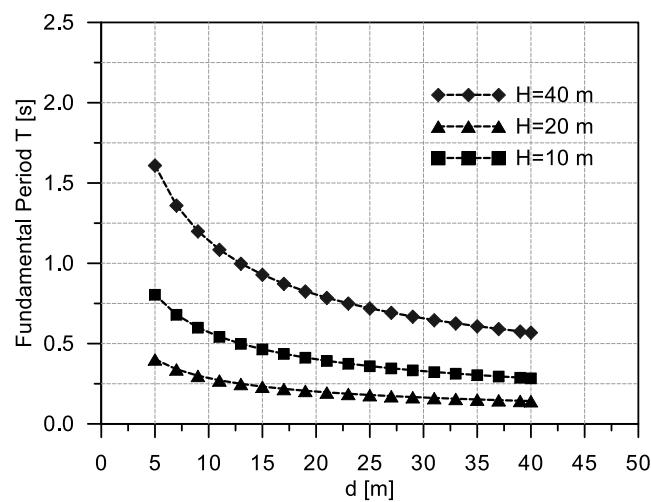

(a)

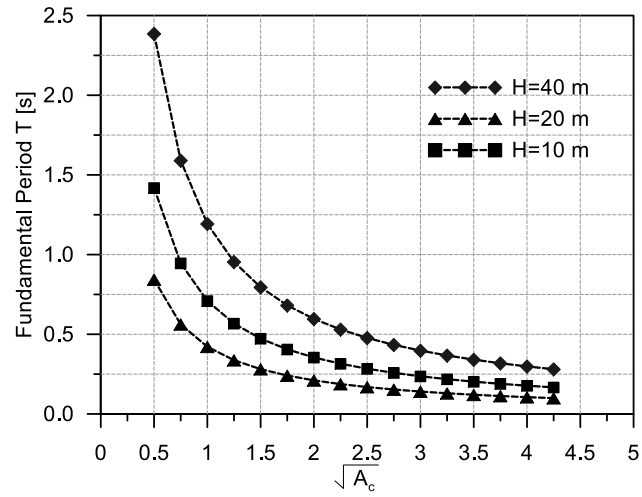

(b)

Fig. 2 Influence of parameter $\mathrm{d}$ and $\mathrm{A}_{\mathrm{c}}$ on the estimation of fundamental period of RC frame structures: $(a)$ influence of $\mathrm{d} ;(b)$ influence of $\mathrm{A}_{\mathrm{c}}$

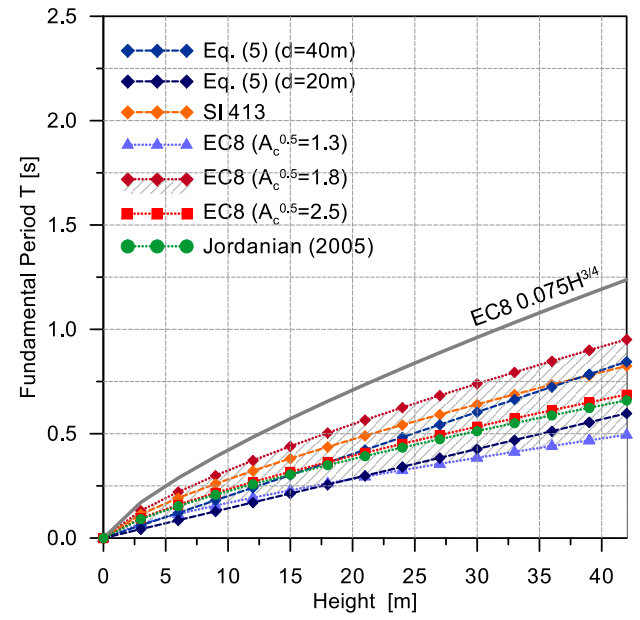

Fig. 3 Comparison of code expressions for the estimation of fundamental period of masonry infilled RC structures 
In an ENV version of EC8 a different approach for the determination of the fundamental period was followed. The relationship proposed (Eq. (11)) was derived in this case considering two parallel single degree of freedom systems, the first associated the stiffness of the bare structure, the second associated the stiffness of a cantilever having shear deformability only

$$
T=T_{1 b} / \sqrt{1+\frac{T_{l b}^{2} A_{w} \cdot G \cdot g}{16 \cdot H \cdot W}}
$$

In Eq. (11) $T_{1 b}$ is the fundamental period associated to the bare structure, $A_{w}$ is the overall area of masonry walls at the base level, $W$ the seismic weight, $G$ the shear modulus, $g$ the gravitational acceleration. In the same ENV version the EC8 also propose a simpler way to calculate the fundamental period as the minimum of the results of the following expressions (symbols have the same meaning of those previously adopted)

$$
T=\min \left\{\begin{array}{l}
0.065 N \\
0.09 \frac{H}{\sqrt{d}}\left(\frac{H}{H+d}\right) \\
0.075 H^{0.75}
\end{array}\right.
$$

Finally a few codes (EC8 2004, NSR-98 1998, NSCP 1992, Costa Rican code 1986, Venezuelan code 1988 and Algerian Code 1988) allow also the use of the Rayleigh formula to calculate the fundamental period based on the methods of structural dynamics

$$
T=2 \pi \sqrt{\frac{\sum_{i=1}^{N} W_{i} \delta_{e i}^{2}}{g \sum_{i=1}^{N} F_{i} \delta_{e i}}}
$$

The symbols $W_{i}, \delta_{e}, F_{i}$ represent the seismic weight, the elastic displacement and the seismic force at the level $i$ respectively. The elastic displacement is determined calculating a first value of $T$ by one of the available empirical expressions. The EC8 provides moreover the following simplified Rayleigh formula for $T$

$$
T=2 \sqrt{\Delta}
$$

In which $\Delta$ is the top displacement calculated applying horizontally the acting gravity loads.

The estimation of the fundamental period results however more reliable when carried out by the empirical formulations rather than by structural dynamics methods, because of the still present uncertainties affecting the structural identification of masonry infill walls.

\subsection{Empirical and semi-empirical expressions derived from FE modelling}

Further height-related formulas for the estimation of the fundamental period of masonry infilled $\mathrm{RC}$ frames have been proposed by several researchers. Among these, different contributions have been provided by Crowley and Pinho $(2004,2006,2010)$, who focused the attention on existing 
RC infilled frame systems and highlighted the importance and the necessity to calibrate regionspecific simplified period-height formulae. Crowley and Pinho (2006) studied the elastic and yield period for use in large-scale vulnerability assessment applications, carrying out eigenvalue and pushover analyses for building models representative of the Europeans stock. Specific expressions, reported in Table 1, were derived for RC frames at the uncracked and cracked stage. Similar results could be attained by means of the expressions proposed by Goel and Chopra (1997) and Chopra and Goel (2000).

Hong and Hwang (2000) measured the period of vibration of a stock of 21 Taiwanese RC infilled buildings. In their formula a really low value of $C_{\mathrm{t}}$ appears and is justified by the major stiffness recognized for Taiwanese buildings. Guler et al. (2008) proposed a relationship derived by ambient vibration tests and elastic numerical analyses obtaining really similar results to those by Hong and Hwang (2000).

The above described empirical and semi-empirical formulas are summarized in Table 1. A graphical comparison of the results is reported in Fig. 4.

Table 1 Expressions for the evaluation of fundamental period of vibration proposed by different authors

\begin{tabular}{cc}
\hline \hline Author & Formula \\
\hline Goel and Chopra (1997) & $T=0.053 H^{0.9}$ \\
Hong and Hwang (2000) & $T=0.0294 H^{0.804}$ \\
Chopra and Goel (2000) & $T=0.067 H^{0.9}$ \\
Crowley and Pinho (2006) (uncracked infills) & $T=0.038 H$ \\
Crowley and Pinho (2006) (cracked infills) & $T=0.055 H$ \\
Guler et al. (2008) & $T=0.026 H^{0.9}$ \\
\hline
\end{tabular}

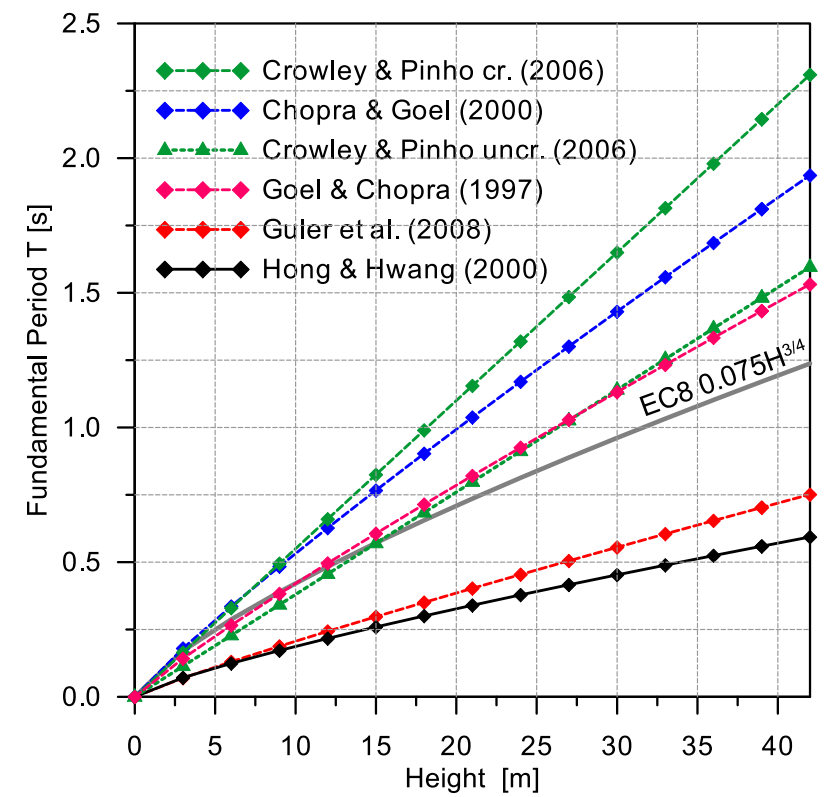

Fig. 4 Comparison of different authors expressions for the estimation of fundamental period of masonry infilled RC structures 
From Fig. 4, it is clearly depicted that the values of the fundamental period based on the expressions proposed by researchers have a spread that is larger than the one obtained by the use of code formulas and reveal the need for further investigations and refinements. The Eq. (1) reference curve is still reported in Fig. 4 and demonstrates an average trend between the other proposals.

Besides the above described proposals, other formulations take into account more aspects in order to achieve a better predictive reliability.

Amanat and Hoque (2006) recognized that the span length, the number of spans and the amount of infills significantly influence the fundamental period. The investigation was carried out on a series of regular $\mathrm{RC}$ framed buildings using a 3D finite-element modelling and modal eigenvalue analysis. The authors proposed an equation based on the determination of 3 modification coefficients, determining $T$ as follows

$$
T=\alpha_{1} \alpha_{2} \alpha_{3} C_{t} H^{0.75}
$$

where $C_{\mathrm{t}}=0.073$ for RC buildings, and the coefficients $\alpha_{1}, \alpha_{2}$ and $\alpha_{3}$ account for span length of infill panels, number of spans and amount of infills, respectively.

More complex expressions have been derived by Hatzigeorgiou and Kanapitsas (2013) and Kose (2009). The first proposed an empirical relationship taking simultaneously into account for the soil flexibility, the influence of shear walls, and of the external and internal infill walls. A database of 20 full scale RC buildings built in Greece was used as basic reference deriving the following expression

$$
T=\frac{H^{\mathrm{C}_{1}} d^{\mathrm{C}_{2}}\left(\mathrm{c}_{3}+\mathrm{c}_{4} W\right)}{\left[1-\exp \left(\mathrm{c}_{5} k_{\mathrm{S}}^{\mathrm{c} 6}\right)\right] \sqrt{\left(1+\mathrm{c}_{7} \rho\right)}}
$$

where $H$ and $d$ have the same meaning, $\rho$ is the ratio of the areas of shear wall to the total area of walls and columns, $k_{\mathrm{s}}$ is the subgrade modulus of soil (in $\mathrm{MN} / \mathrm{m}^{3}$ ) and $\mathrm{W}$ a parameter considering the influence of infill walls. A nonlinear regression analysis allowed the derivation of coefficients $c_{1}-c_{7}$. If one neglects the influence of infills and concrete shear walls, of soil flexibility and of the building length, Eq. (16) returns a simpler expression which is really similar to the formula provided by the Eurocode 8

$$
T=0.073 H^{0.745}
$$

An iterative 3D modal analysis was carried by Kose (2009) for the investigation of the fundamental period of vibration of RC frame buildings. The effects of building height, frame type and the presence of infill walls were considered besides those of other parameters. The fundamental period $T$ was expressed as sum of the different contributions which may be additive or subtractive

$$
T=0.0935+0.0301 H+0.0156 B+0.039 F-0.1656 S-0.0232 I
$$

In Eq. (18) $H$ is still the height of the building in meters, $B$ the number of bays, $F$ is equal to 1 for frames with infills, 2 for frames with open first floor and 3 for bare frames, $S$ is the percentage ratio of shear walls to total floor area, $I$ is the ratio of the area of infill walls to total area of the panels. The same author recognized that, based on the sensitivity analysis undertaken, the fundamental period was not too sensitive to the number of bays and frame type, therefore the following simpler expression was proposed 


$$
T=0.1367+0.0301 H-0.1663 S-0.0305 I
$$

A significant number of models have been considered in the previous review. They included simple empirical height-related expressions, structural dynamics formulations and more complex relationships taking into account different parameters and derived by the results of refined $\mathrm{FE}$ simulations. It is evident how the determination of the fundamental period for a generic structure, carried out by the different models, leads to a large spread of the results. The common interpretation attributes this to the fact that, in most of the cases, the proposed expressions are calibrated on the basis of experiences on structural typologies belonging to specific regions or countries. Moreover, as highlighted by Crowley and Pinho (2010) it is reasonable to think that buildings designed according to older design codes, and therefore generally with less restrictive rules, have larger fundamental periods than the more recent ones. Therefore comparisons made on constructions belonging to substantially different periods necessarily lead to incongruent results.

In consideration of what recognized, a deeper investigation of the parameters affecting the fundamental period of vibration of masonry infilled RC structures seems to be necessary in order to provide more reliable and accurate predictive relationships to be used in practical applications.

\section{Description of the structures}

\subsection{Building forms and infill walls parameters}

In this study, the parameters affecting the fundamental period of infilled RC plane frame structures are investigated. Buildings investigated have 8 and 14 storeys (Fig. 5). The storey height

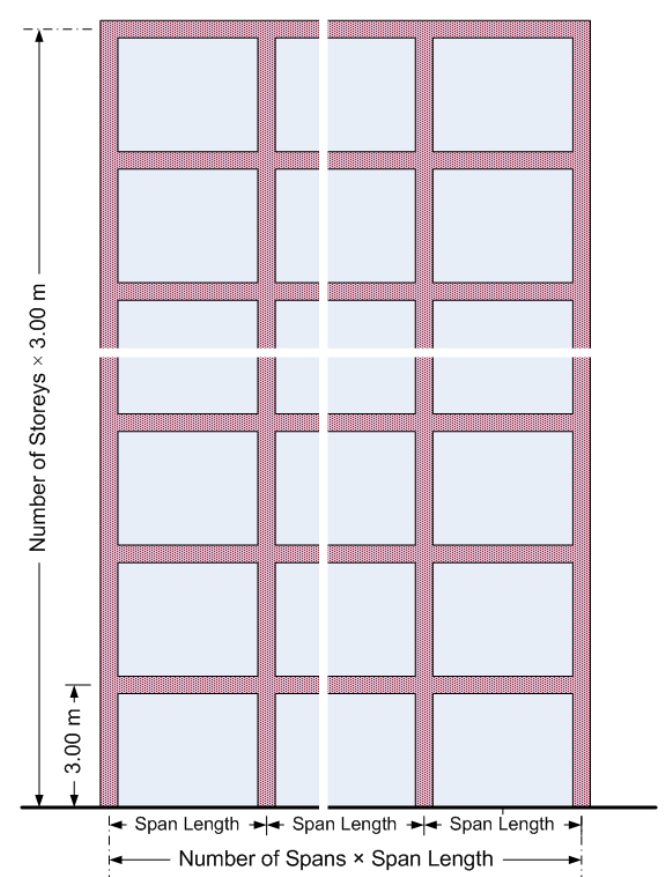

Fig. 5 Cross section details of a RC infilled frame 
Table 2 Building parameters

\begin{tabular}{cc}
\hline \hline Concrete strength & $25 \mathrm{MPa}$ \\
Modulus of elasticity of concrete, $E_{c}$ & $31 \mathrm{GPa}$ \\
Steel tensile yield strength & $500 \mathrm{MPa}$ \\
Size of beams & $250 / 600 \mathrm{~mm}$ \\
Slab thickness & $150 \mathrm{~mm}$ \\
Dead loads & $1.50 \mathrm{kN} / \mathrm{m}^{2}+0.90 \mathrm{kN} / \mathrm{m}^{2}$ \\
Live loads & $3.50 \mathrm{kN} / \mathrm{m}^{2}$ \\
Number of floors & 8,14 \\
Building height & $24 \mathrm{~m}, 42 \mathrm{~m}$ \\
Span length & $3.0 \mathrm{~m}, 4.5 \mathrm{~m}, 6.0 \mathrm{~m}, 7.5 \mathrm{~m}$ \\
Number of spans & $2,4,6$ \\
Masonry compressive strength, $f_{m}$ & $1.5 \mathrm{MPa}, 3.0 \mathrm{MPa}, 4.5 \mathrm{MPa}, 8.0 \mathrm{MPa}, 10.0 \mathrm{MPa}$ \\
Modulus of elasticity of masonry, $E_{m}$ & $1.5 \mathrm{GPa}, 3.0 \mathrm{GPa}, 4.5 \mathrm{GPa}, 8.0 \mathrm{GPa}, 10.0 \mathrm{GPa}$ \\
Thickness of infill panel, $t_{w}$ & $150 \mathrm{~mm}, 250 \mathrm{~mm}$ \\
Infill wall opening percentage & $0 \%$ (fully infilled), $25 \%, 50 \%, 75 \%, 100 \%$ (bare frame) \\
\hline
\end{tabular}

for all buildings is kept constant and equal to $3.0 \mathrm{~m}$. The number of spans varied between 2, 4 and 6. For each case, four different span lengths were considered, namely $3.0 \mathrm{~m}, 4.5 \mathrm{~m}, 6.0 \mathrm{~m}$ and 7.5 $\mathrm{m}$. In the perpendicular direction the span length has been kept constant and equal to $5 \mathrm{~m}$ for all cases.

Both bare frame structures as well as structures with fully or partially unreinforced masonry infilled frames with or without openings are analysed, in order to examine the influence of infill walls. Various parameters are considered for each case. Infill panels are either 0.15 or $0.25 \mathrm{~m}$ thick, following the conventional construction of single and double leaf walls. The influence of infill wall openings is also examined. Infill wall openings are given as a percentage of the panel area. Five different cases for infill wall openings are studied. These are: fully infilled walls $(0 \%$ openings), infill walls with small and large openings (25\%, 50\% and $75 \%$ openings) and bare frames (100\% openings).

Moreover, five different values for the masonry panel strength were adopted to represent weak, medium and strong masonry, namely 1.5 MPa, 3.0 MPa, 4.5 MPa, 8.0 MPa and 10.0 MPa. These values are assumed to cover the most common cases for masonry infill condition in Europe.

The building parameters used for the development of the model are listed in Table 2.

\subsection{Design of structures}

The frames were designed according to Eurocode standards using the software FESPA (LH Logismiki 2013). Modal response spectrum analysis was also performed. The frames were designed for seismic zone I with reference peak ground acceleration on type A ground, $a_{g R}=0.16 \mathrm{~g}$. The importance factor $\gamma_{I}$ was taken as 1.0 and the ground type as B with soil factor $S$ equal to 1.2, according to Eurocode 8. Frames designed for medium ductility class (DCM) and the behaviour factor, $q$ assumed to be 3.45 . Concrete strength class C25/30 was used for beams and columns, while steel grade B500c was used for the reinforcement steel bars. The dead load was $1.50 \mathrm{kN} / \mathrm{m}^{2}$ 
Table 3 Side dimension (mm) of square columns

\begin{tabular}{|c|c|c|c|c|c|c|c|c|}
\hline \multirow{4}{*}{ Storey } & \multicolumn{8}{|c|}{ Column's Dimensions (mm) } \\
\hline & \multicolumn{4}{|c|}{ 14-storeys } & \multicolumn{4}{|c|}{ 8-storeys } \\
\hline & \multicolumn{8}{|c|}{ Span length } \\
\hline & $3.0 \mathrm{~m}$ & $4.5 \mathrm{~m}$ & $6.0 \mathrm{~m}$ & $7.5 \mathrm{~m}$ & $3.0 \mathrm{~m}$ & $4.5 \mathrm{~m}$ & $6.0 \mathrm{~m}$ & $7.5 \mathrm{~m}$ \\
\hline 14 & 400 & 400 & 500 & 650 & & & & \\
\hline 13 & 450 & 450 & 550 & 650 & & & & \\
\hline 12 & 450 & 450 & 550 & 650 & & & & \\
\hline 11 & 450 & 500 & 550 & 650 & & & & \\
\hline 10 & 500 & 500 & 550 & 650 & & & & \\
\hline 9 & 500 & 500 & 550 & 650 & & & & \\
\hline 8 & 500 & 500 & 600 & 650 & 350 & 400 & 500 & 650 \\
\hline 7 & 500 & 550 & 600 & 650 & 400 & 450 & 550 & 650 \\
\hline 6 & 500 & 550 & 600 & 700 & 450 & 500 & 550 & 650 \\
\hline 5 & 500 & 600 & 650 & 700 & 450 & 500 & 550 & 650 \\
\hline 4 & 550 & 600 & 650 & 700 & 500 & 500 & 600 & 650 \\
\hline 3 & 550 & 600 & 650 & 700 & 500 & 550 & 650 & 650 \\
\hline 2 & 550 & 600 & 650 & 700 & 500 & 550 & 650 & 650 \\
\hline 1 & 550 & 600 & 650 & 700 & 500 & 550 & 650 & 650 \\
\hline
\end{tabular}

plus $0.90 \mathrm{kN} / \mathrm{m}^{2}$ to include interior partition walls in the mass of the building. Live load is 3.5 $\mathrm{kN} / \mathrm{m}^{2}$.

Slabs were $150 \mathrm{~mm}$ thick for all cases. Beams were $250 / 600 \mathrm{~mm}$ for all frames. Square column sections were used for all frames. For the fourteen storey frame with $7.5 \mathrm{~m}$ span length, columns had dimensions ranging from $700 \times 700[\mathrm{~mm}]$ at the ground floor to $650 \times 650[\mathrm{~mm}]$ at the roof. For the eight storey frame with $3.0 \mathrm{~m}$ span length, column dimensions range from $500 \times 500[\mathrm{~mm}]$ to $350 \times 350$ [mm]. Column longitudinal reinforcement ratio was kept low and ranged between $1.0 \%$ and $1.5 \%$, with most cases being under $1.15 \%$. Column dimensions for all frames are shown in detail in Table 3. Column dimensions were kept the same for buildings with the same number of storeys, same span length but different number of spans.

\section{Modelling and validation}

\subsection{General}

Since the first attempts to model the response of the composite infilled-frame structures, experimental and conceptual observations have indicated that a diagonal strut with appropriate geometrical and mechanical characteristics could possibly provide a solution to the problem (Fig. 6). In Fig. $6 w$ is the width of the diagonal strut, $d$ is the diagonal length of the masonry panel, $L$ is the distance between the centres of two columns and $z$ is the contact length of the diagonal strut to the column. 


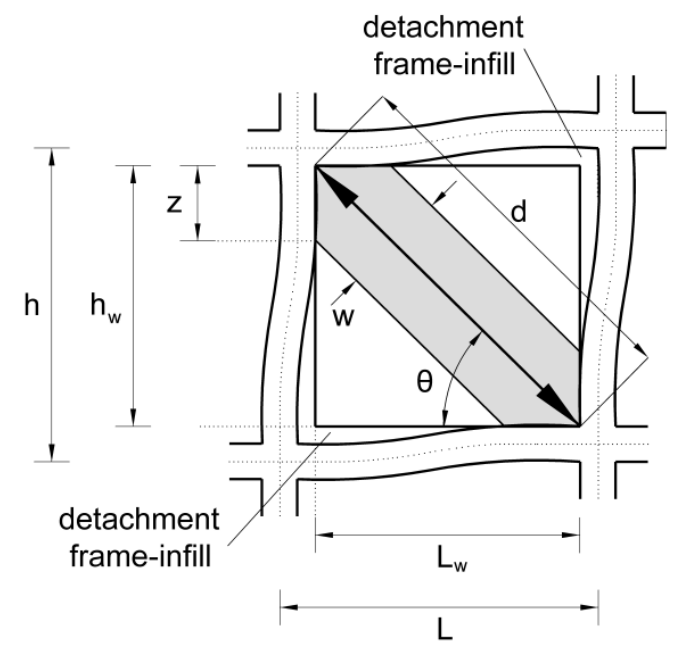

Fig. 6 Masonry infill frame sub-assemblage

Early research on the in-plane behaviour of infilled frame structures undertaken at the Building Research Station, Watford (later renamed Building Research Establishment, and now simply BRE) in the 1950s served as an early insight into this behaviour and confirmed its highly indeterminate nature in terms solely of the normal parameters of design (Thomas 1953, Wood 1959). On the basis of these few tests a purely empirical interaction formula was later tentatively suggested by Wood (1959) for the design of tall framed buildings. By expressing the composite strength of an infilled frame directly in terms of the separate strengths of the frame and infill, Wood (1959) shortcircuited a mass of confusing detail and recognized the desirability of a higher load factor where strengths were most dependent on the infills.

\subsection{Modelling of structures}

All buildings were modelled as plane frames using Seismostruct (Seismosoft 2013). A plastichinge element has been adopted for beams and columns, with concentrated inelasticity within a fixed length at each member's end. The Mander et al. (1988) model, later modified by MartinezRueda and Elnashai (1997), has been assumed for the core and the unconfined concrete, while Menegotto-Pinto steel model has been adopted for the reinforcement steel (Menegotto and Pinto 1997). Concrete compressive strength was equal to $25 \mathrm{MPa}$ and the yield strength of the steel equal to $500 \mathrm{MPa}$. Mass was calculated using the seismic load combination, namely dead loads plus $30 \%$ of the live loads.

Masonry is modelled using the inelastic infill panel element. This is an equivalent strut nonlinear cyclic model proposed by Crisafulli (1997) for the modelling of the nonlinear response of infill panels in framed structures. Each panel is represented by six strut members. Each diagonal direction features two parallel struts to carry axial loads across two opposite diagonal corners and a third one to carry the shear from the top to the bottom of the panel (Fig. 7). The struts act only across the diagonal that is on compression, hence, its "activation" depends on the deformation of the panel. The axial load struts use the masonry strut hysteresis model, while the shear strut uses a dedicated bilinear hysteresis rule, as described by Crisafulli (1997). 


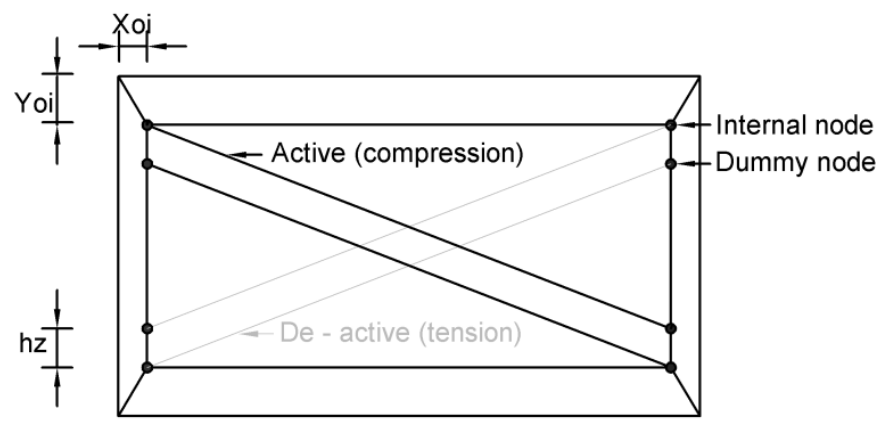

(a)

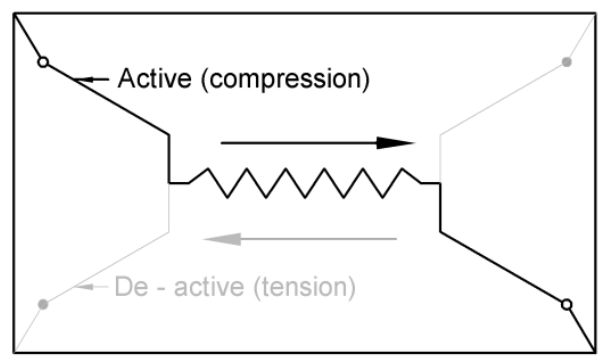

(b)

Fig. 7 Infill panel element proposed by Crisafulli (1997). (a) Compression/Tension Struts, (b) Shear Strut

Four internal nodes are employed to account for the actual points of contact between the frame and the infill panel (i.e., to account for the width and height of the columns and beams, respectively), whilst four dummy nodes are introduced with the objective of accounting for the contact length between the frame and the infill panel (Fig. 7). All the internal forces are transformed to the exterior four nodes where the element is connected to the frame. In Fig. $7 x_{\mathrm{oi}}$ and $y_{\mathrm{oi}}$ is the horizontal and the vertical distance between the external corner nodes (middle of the beam-column joint) and the internal ones (point of contact of the masonry with the RC frame), accordingly. In the same Figure $h_{\mathrm{z}}$ is the equivalent contact length. Seismostruct [2013] suggests that reasonable results are obtained for values equal to $1 / 3$ of the actual contact length $(z)$, defined by Smith (1966) as equal to $0.5 \pi\left(\lambda_{h} / h\right)^{-1},\left(\lambda_{h}\right.$ according to Eq. (21)). Infill walls with openings are modelled with the same element but reduced stiffness, according to Eq. (25). Detailed and indepth description on the parameters used in Crisafulli model can be found in Smyrou et al. (2011).

The fundamental periods are calculated with eigenvalue analyses based on the linear model with initial stiffness conditions for all components.

\subsection{Infill walls modelling}

\subsubsection{Infill walls without openings}

In the early sixties, Polyakov (1960) suggested the possibility of considering the effect of the infill in each panel as equivalent to diagonal bracing. This suggestion was later adopted by Holmes (1961) who replaced the infill by an equivalent pin-jointed diagonal strut made of the same material and having the same thickness as the infill panel and a width, $w$, defined by

$$
\frac{w}{d}=\frac{1}{3}
$$

where, $d$ is the diagonal length of the masonry panel (Fig. 6). The "one-third" rule was suggested as being applicable irrespective of the relative stiffness of the frame and the infill. One year later, Smith (1962), based on experimental data from a large series of tests using masonry infilled steel frames, found that the ratio $w / d$ varied from 0.10 to 0.25 . In the second half of the sixties Smith (1966) using additional experimental data related the width of the equivalent diagonal strut to the infill/frame contact lengths using an analytical equation, which has been adapted from the equation of the length of contact of a free beam on an elastic foundation subjected to a concentrated load 
(Hetenyi 1946). They proposed the evaluation of the equivalent width as a function of the relative panel-to-frame-stiffness parameter, in terms of

$$
\lambda_{h}=h \sqrt[4]{\frac{E_{w} t_{w} \sin 2 \theta}{4 E I h_{w}}}
$$

where $E_{\mathrm{w}}$ is the modulus of elasticity of the masonry panel, $E I$ is the flexural rigidity of the columns, $t_{\mathrm{w}}$ the thickness of the infill panel and equivalent strut, $h$ the column height between centerlines of beams, $h_{\mathrm{w}}$ the height of infill panel, and $\theta$ the angle, whose tangent is the infill height-to-length aspect ratio, being equal to

$$
\theta=\tan ^{-1}\left(\frac{h_{w}}{L_{w}}\right)
$$

where $L_{w}$ is the length of infill panel. All the above parameters are explained in Fig. 6. Based on experimental and analytical data, Mainstone (1971) proposed an empirical equation for the calculation of the equivalent strut width, given by

$$
\frac{w}{d}=0.16 \lambda_{h}^{-0.3}
$$

Later, Mainstone and Weeks (1970) and Mainstone (1974) based on experimental and analytical data, proposed an empirical equation for the calculation of the equivalent strut width as follows

$$
\frac{w}{d}=0.175 \lambda_{h}^{-0.4}
$$

Eq. (24) was included in FEMA-274 (Federal Emergency Management Agency 1997) for the analysis and rehabilitation of buildings as well as in FEMA-306 (Federal Emergency Management Agency 1998), as it has been proven to be the most popular over the years. This equation was accepted by the majority of researchers dealing with the analysis of infilled frames.

\subsubsection{Infill walls with openings}

Most of recent research investigates the behaviour of infilled walls without openings although infill walls often have oversized openings. Asteris $(2003$, 2008) proposed a finite element technique in order to estimate the infill/frame contact lengths and this technique was then used to investigate the effect of openings on the lateral stiffness of masonry infill walls.

Infill walls with different opening sizes were analysed and their lateral stiffness was estimated. Fig. 8 shows the variation of the infill panel stiffness reduction factor $\lambda$ as a function of the opening percentage (opening area/infill wall area), for the case of an opening on the compressed diagonal of the infill wall (with aspect ratio of the opening the same as that of the infill). As expected, the increase in the opening percentage leads to a decrease in the frame's stiffness. Specifically, for an opening percentage greater than $50 \%$ the stiffness reduction factor tends to zero. The findings of the parametric study by Asteris (2003) using the finite-element method, lead to the following relationship for the infill wall stiffness reduction factor $\lambda$ 


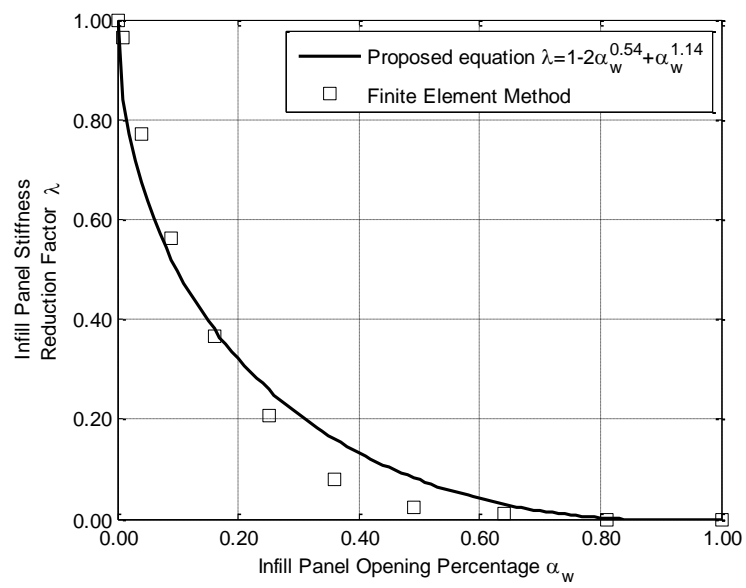

Fig. 8 Infill panel stiffness reduction factor in relation to the opening percentage

$$
\lambda=1-2 \alpha_{\mathrm{w}}^{0.54}+\alpha_{\mathrm{w}}^{1.14}
$$

where $\alpha_{w}$ is the ratio of the area of opening to the area of infill wall. The above coefficient could be used to find the equivalent width of a strut for the case of an infill with opening by multiplying the width obtained using Eqs. (20), (23) and (24) by the relevant reduction factor. In this study, this coefficient is used to modify the equations of the Crisafulli model, described in section 4.2.

\subsection{Soil-structure interaction (SSI)}

It is well known that soil flexibility elongates the fundamental period of the structure. In order to examine the influence of the soil conditions on the fundamental period, soil-structure interaction is taken into account in the current study.

Foundation is considered to be continuous spread footing with $2.5 \mathrm{~m}$ width. Vertical springs are used to simulate the soil-structure interaction in the 2D modelling. Especially a translational spring is introduced by using a link element, characterized by a stiffness $k$ in the vertical direction, for the following soil types:

- Rigid soil $(k=\infty)$, that is, fixed boundary conditions for the foundation.

- Rock ( $k=13,500,000 \mathrm{kN} / \mathrm{m})$, ground type A according to EC8 (2004).

- Dense sand $(k=7,000,000 \mathrm{kN} / \mathrm{m})$, ground type B according to EC8 (2004).

- Medium dense sand $(k=1,500,000 \mathrm{kN} / \mathrm{m})$, ground type C according to EC8 (2004).

- Loose to medium cohesionless soil $(k=450,000 \mathrm{kN} / \mathrm{m})$, ground type D according to EC8 (2004).

\subsection{Sensitivity analysis}

In order to evaluate the influence of certain parameters of the infill strut model on the estimation of the fundamental period of the structure sensitivity analysis is carried out. The masonry infill strut model used in the current study requires the definition of some empirical factors. The factors that influence the estimation of the fundamental period are the equivalent contact length, $h_{z}$, the proportion of stiffness assigned to shear, $\gamma_{s}$ and the equivalent width, $w$, of 
the diagonal strut. Sensitivity analysis aims at identifying the impact of these variables on the fundamental period of the structure.

The equivalent contact length, $h_{z}$ (Fig. 7), is used to somehow take into account the contact length between the frame and the infill panel. According to Seismostruct (Seismosoft 2013) reasonable results seem to be obtained for values of $1 / 3$ to $1 / 2$ of the actual contact length $(z)$, defined by Smith (1966) as equal to $0.5 \pi\left(\lambda_{h} / h\right)^{-1},\left(\lambda_{h}\right.$ according to Eq. (21)). Value used in the current study is $1 / 3$, as previously mentioned in section 4.2 .

The proportion of stiffness assigned to shear, $\gamma_{\mathrm{s}}$, represents the proportion of the panel stiffness (computed internally by the program) that should be assigned to the shear spring. According to Seismostruct (Seismosoft 2013) this value typically ranges between 0.2 and 0.6. In this study a value of 0.6 is adopted.

The equivalent strut width, $w$, is evaluated using Eq. (24) proposed by Mainstone (1974). For sensitivity analysis equivalent strut width is evaluated using Eq. (20) by Holmes (1961) and Eq. (23) by Mainstone (1971). The equivalent strut width is also evaluated using Eq. (24), but using the span length and height of the storey, instead of the panel dimensions.

Fig. 9 shows the change in the fundamental period between the model used in the present study (which has equivalent contact length, $h_{z}$, equal to $1 / 3$ of the actual contact length $(z)$, proportion of stiffness assigned to shear, $\gamma_{s}$, equal to 0.6 and equivalent strut width, w, evaluated using Eq. (24) proposed by Mainstone (1974)) and models with different values for these parameters. It can be seen that the equivalent contact length does not significantly influence the fundamental period of the structure. The proportion of stiffness assigned to shear has a small influence. Extreme values of $\gamma_{s}$, proposed by Seismostruct (Seismosoft 2013), result in $4.3 \%$ difference on the fundamental period. Finally, the equivalent strut width significantly affects the estimation of the fundamental period. If the equivalent strut width is evaluated using the span length and height of the storey instead of the panel dimensions then the fundamental period changes by $5 \%$. However, evaluation the equivalent strut width using Eq. (20) instead of Eq. (24) will result to $27 \%$ reduction of the fundamental period.

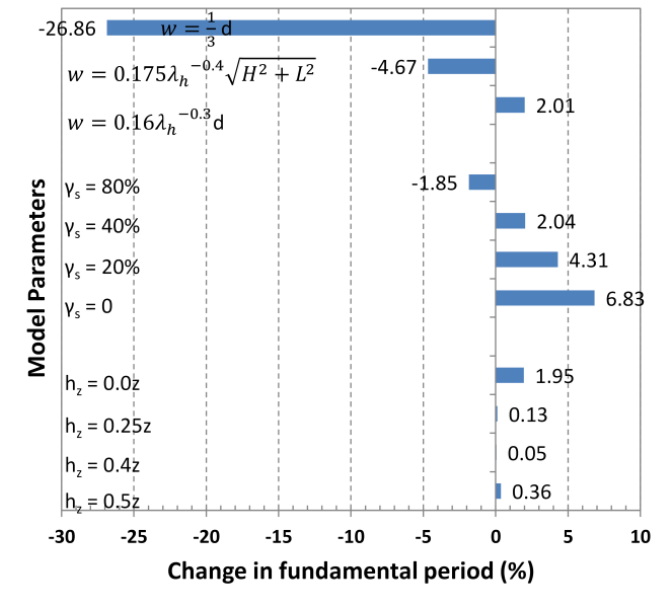

(a) 8-storey frame

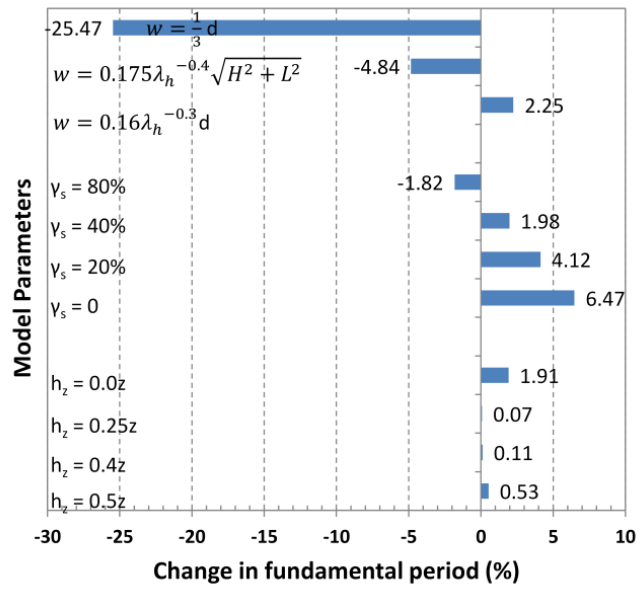

(b) 14-storey frame

Fig. 9 Sensitivity analysis results of infill model parameters in terms of deviation from the original model. (a) 8-storey and (b) 14-storey with 6 spans and 6 m span length 


\subsection{Validation of the model}

Modelling of infill walls is very important and can significantly influence the behaviour of the whole structure. The behaviour of solid infill walls can be represented with sufficient accuracy using single-strut models. On the other hand, a reliable modelling of infill walls with openings is more difficult and according to FEMA-356 (Federal Emergency Management Agency 2000) if a single-strut model is used, it must be calibrated using finite-element analysis.

In order to validate the model, a case study was previously carried out by Asteris et al. (2011) employing a reinforced concrete frame with infill walls. In that study infill walls were modelled using either a single-strut model or the double-strut model proposed by Crisafulli (1997), described in section 4.2. The accuracy of the models was assessed through comparison with experimental results obtained from pseudo-dynamic tests of a full-scale, four-storey, three-bay, reinforced concrete frame, which was tested at the European Laboratory for Structural Assessment (ELSA) reaction-wall laboratory within the framework of the Innovative Seismic Design Concepts for New and Existing Structures (ICONS) research program (Pinto et al. 2002). The RC frame, infilled with brick walls including openings, is representative of the design construction practice of the 1960s in Southern Europe. From the comparison of experimental and numerical results, it was shown that the double-strut model by Crisafulli (1997) provided a very good fit to the experimental results. On the contrary, the single strut model could not adequately represent the experimental behaviour. Thus, the double-strut model by Crisafulli (1997) was chosen for modelling the infill walls in the present study.

\section{Results and discussion}

\subsection{Influence of the number of spans on the fundamental period}

In order to investigate the influence of the number of spans on the fundamental period, buildings with 2, 4 and 6 spans were analysed. Fig. 10 shows the relationship between the determined fundamental period of vibration versus the number of spans for both bare and fully infilled 8-storey and 14-storey RC frames. The fundamental periods obtained from the eigenvalue analysis are also compared against the period obtained from EC8 and that from Chopra and Goel (2000). From Fig. 10 and Table 4, it is shown that the fundamental period obtained from modal analysis for both the 8-storey and 14-storey RC infilled frames with span lengths ranging from $3 \mathrm{~m}$ to $7.5 \mathrm{~m}$ is not influenced by the number of spans (Fig. 10(b) and (d)). Also, the fundamental period for the 8-storey for all span lengths examined and for the 14-storey RC bare frames with span lengths ranging from 4.5 to $7.5 \mathrm{~m}$ is not influenced by the number of spans (Fig. 10(a) and (c)). This is in agreement with the findings of Amanat and Hoque (2006). For the 14-storey bare frame with two spans and span length equal to $3 \mathrm{~m}$ (Fig. 10c), the fundamental period is higher when compared to the same frame with four and six spans. Thus, when there are two spans, the building becomes relatively slender and more flexible, since a cantilever action comes into effect against lateral sway, resulting in longer period Most of the equations for the estimation of the fundamental period, proposed by codes or researchers, do not have any parameter relevant to span. From Fig. 10(a) and (c), the modal analysis for the 8-storey bare frame with span lengths ranging from $4.5 \mathrm{~m}$ to $6.0 \mathrm{~m}$ and for the 14-storey bare frame with span lengths ranging from $3.0 \mathrm{~m}$ to 6.0 $\mathrm{m}$ resulted in periods falling within the region of those estimated by the code equations and that of 
Table 4 Fundamental period of an 8-storey and a 14-storey concrete frame

\begin{tabular}{|c|c|c|c|c|c|c|c|c|c|}
\hline \multirow{3}{*}{ Case } & \multirow{3}{*}{$\begin{array}{c}\text { Number } \\
\text { of } \\
\text { Spans }\end{array}$} & \multicolumn{4}{|c|}{ Bare Frame } & \multicolumn{4}{|c|}{ Fully Infilled Frame } \\
\hline & & \multicolumn{4}{|c|}{ Span Length (m) } & \multicolumn{4}{|c|}{ Span Length (m) } \\
\hline & & 3.0 & 4.5 & 6.0 & 7.5 & 3.0 & 4.5 & 6.0 & 7.5 \\
\hline \multirow{3}{*}{ 8-storey } & 2 & 0.735 & 0.890 & 1.021 & 1.189 & 0.466 & 0.502 & 0.537 & 0.587 \\
\hline & 4 & 0.721 & 0.891 & 1.030 & 1.197 & 0.460 & 0.502 & 0.537 & 0.588 \\
\hline & 6 & 0.717 & 0.891 & 1.030 & 1.200 & 0.458 & 0.502 & 0.537 & 0.588 \\
\hline \multirow{3}{*}{ 14-storey } & 2 & 1.410 & 1.594 & 1.883 & 2.203 & 0.824 & 0.869 & 0.952 & 1.043 \\
\hline & 4 & 1.272 & 1.545 & 1.860 & 2.192 & 0.792 & 0.856 & 0.944 & 1.036 \\
\hline & 6 & 1.230 & 1.530 & 1.853 & 2.189 & 0.780 & 0.851 & 0.941 & 1.035 \\
\hline
\end{tabular}

Note: Masonry wall modulus of elasticity $\mathrm{E}=1500 \mathrm{MPa}$;

Masonry wall thickness $\mathrm{t}=0.15 \mathrm{~m}$;

Masonry wall stiffness $\mathrm{Et}=2.25 \cdot 10^{5} \mathrm{kN} / \mathrm{m}$

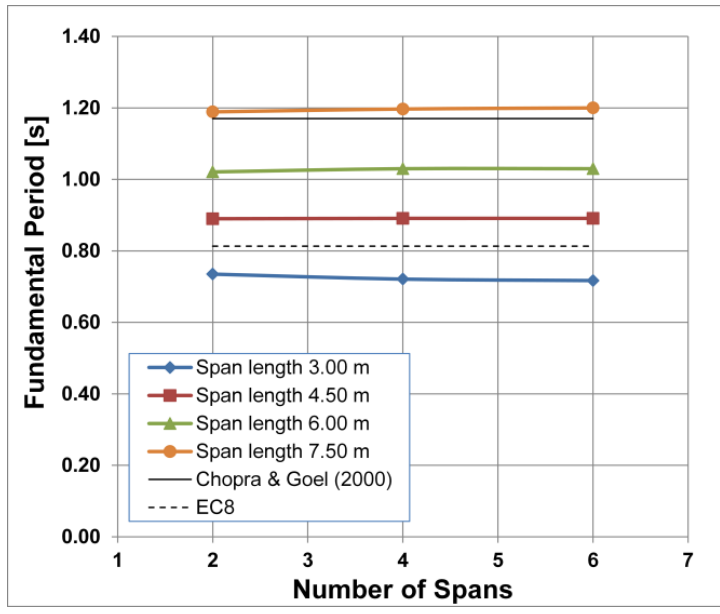

(a) 8-storey bare frame

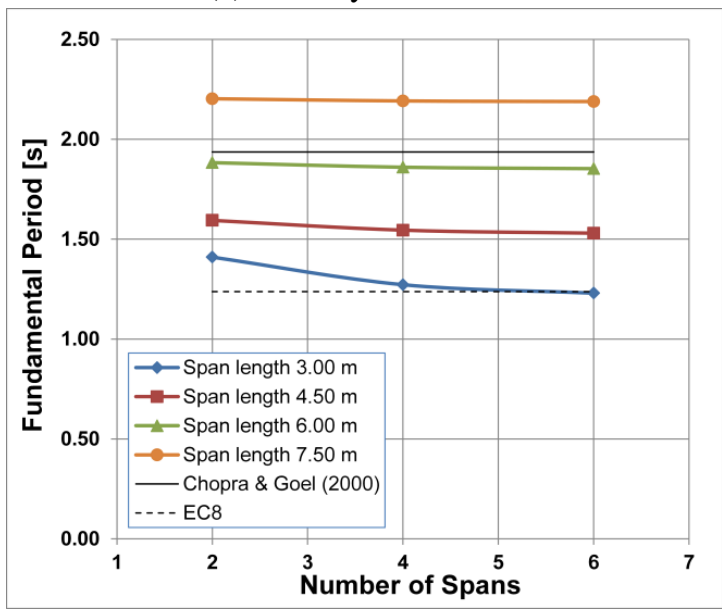

(c) 14-storey bare frame

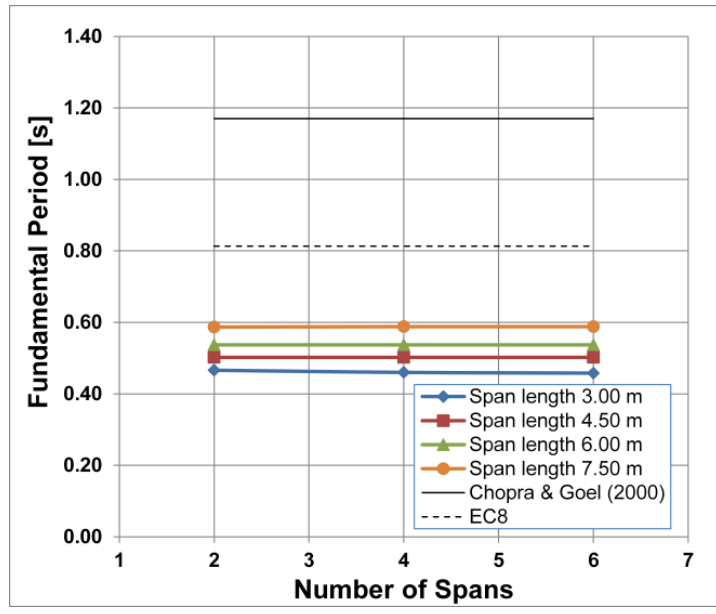

(b) 8-storey fully infilled frame

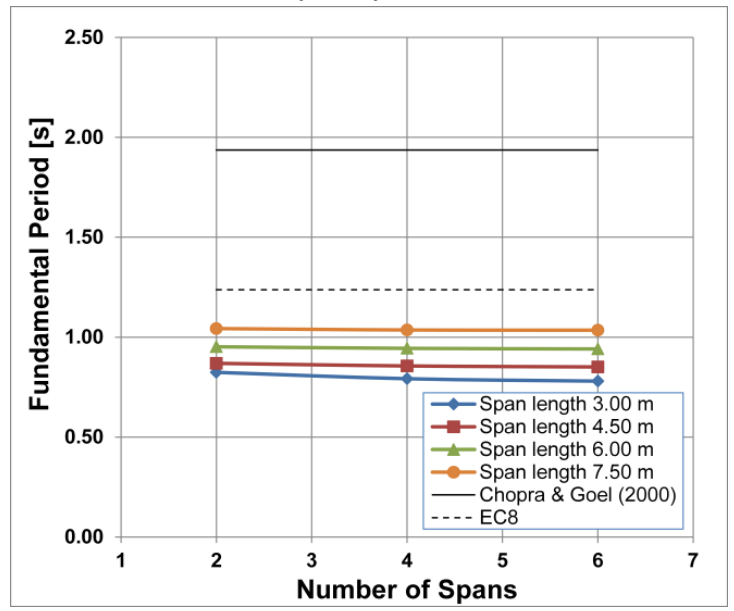

(d) 14-storey fully infilled frame

Fig. 10 Influence of number of spans on fundamental period of an 8-storey and a 14-storey RC frame 
Chopra and Goel (2000). This is not the case for the 8-storey bare frame with span lengths of 3.0 $\mathrm{m}$ and $7.5 \mathrm{~m}$ and for the 14-storey bare frame with span length equal to $7.5 \mathrm{~m}$. On the other hand, from Fig. 10(b) and (d), for the 8-storey and 14-storey fully infilled frame, it is apparent that the values of the determined fundamental period are lower than those obtained from EC8 as well as that from Chopra and Goel (2000).

\subsection{Influence of the span length on the fundamental period}

The influence of the span length on the fundamental period of an 8-storey and a 14-storey RC framed building was subsequently investigated. Different span lengths of 3.0, 4.5, 6.0 and $7.5 \mathrm{~m}$ were chosen for the sensitivity study. Fig. 11 shows the relationship between the determined fundamental period versus the span length for both the 8-storey and a 14-storey, bare and fully infilled, RC frames. Similarly, the time periods obtained from the eigenvalue analysis are also compared against the period obtained from the EC8 equations and that from Chopra and Goel (2000). From Fig. 11 and Table 5, it can be seen that if the span length increases, the period of the $\mathrm{RC}$ building also increases.

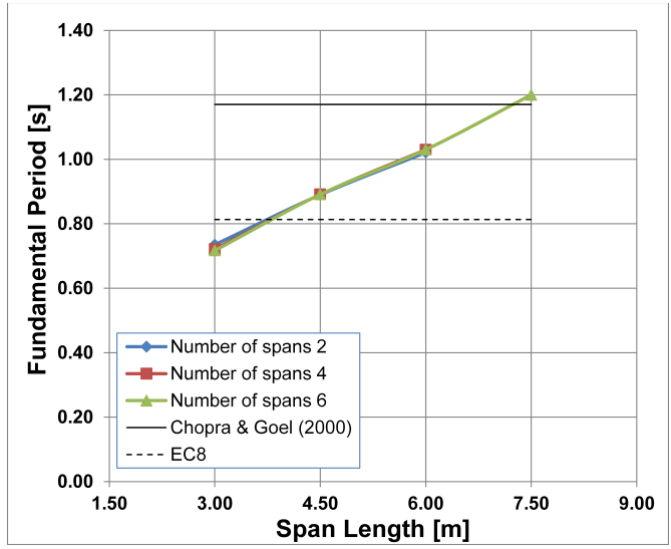

(a) 8-storey bare frame

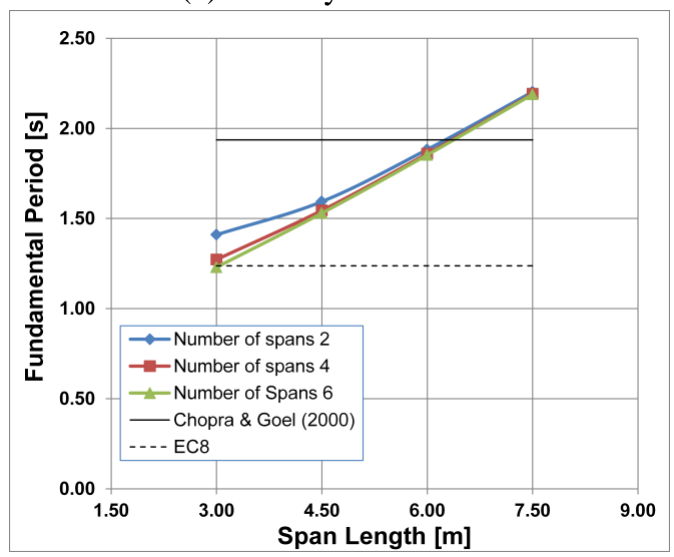

(c) 14-storey bare frame

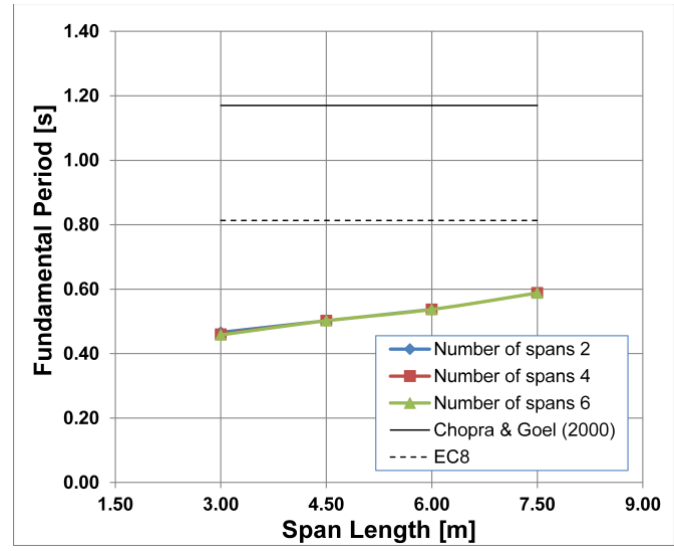

(b) 8-storey fully infilled frame

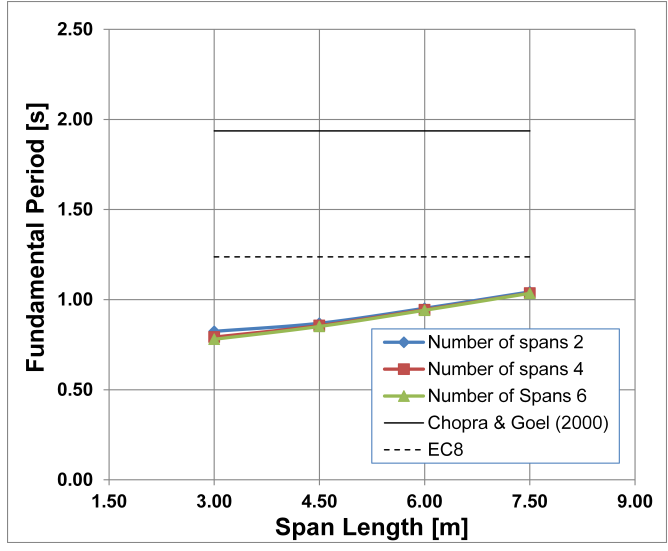

(d) 14-storey fully infilled frame

Fig. 11 Influence of span length on the fundamental period of an 8-storey and a 14-storey RC frame 
For the estimation of the time period of a building, both the code equations and the relationship derived from Chopra and Goel (2000) do not have any provision to incorporate the effect of span lengths in the direction of motion. Therefore, the periods predicted by these equations are the same for all values of span length studied. For the 8-storey bare frame with span length ranging from 4.5 $\mathrm{m}$ to $6.0 \mathrm{~m}$ and for the 14-storey bare frame with span lengths ranging from $3.0 \mathrm{~m}$ to $6.0 \mathrm{~m}$ (Fig. 11a and c), the values of the determined fundamental period fall within the range of the values suggested by the code equations and that from Chopra and Goel (2000). But, this is not the case for the rest of the cases studied. It is important to mention that the influence of the span length corresponds to infill length-to-height aspect ratio equal to 1.0, 1.5, 2.0 and 2.5 accordingly. From Fig. 11 and Fig. 12, it is clear that an increase in span length influence more the bare than the infilled frames. The period increases by about $67 \%$ for $4.5 \mathrm{~m}$ increase of the span, compared to the reference value of $3 \mathrm{~m}$, for the 8 -storey bare frame and by $78 \%$ for the 14 -storey bare RC frame with six spans (Fig. 12a). Similarly, from Fig. 12(b) it can be seen that the period increases by about $28 \%$ for $4.5 \mathrm{~m}$ increase of the span compared to the reference value of $3 \mathrm{~m}$ for the 8 -storey fully infilled frame and by $33 \%$ for the 14-storey fully infilled RC frame with six spans.

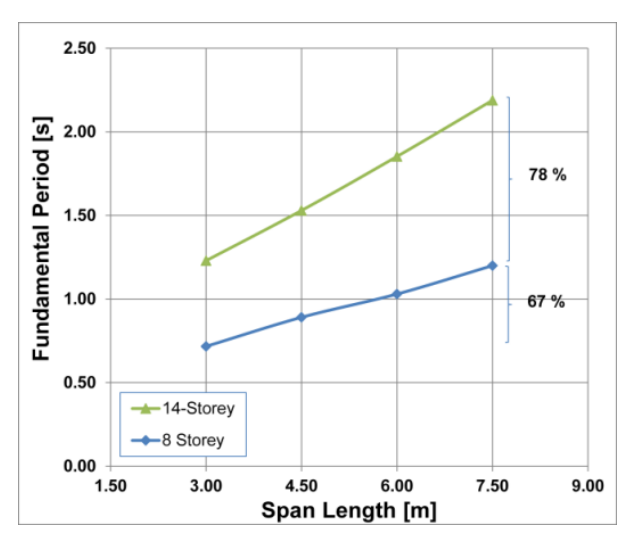

(a) Bare frame

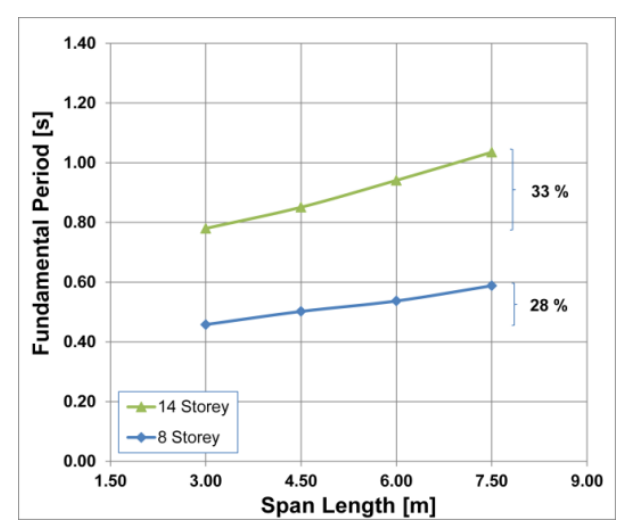

(b) Fully infilled frame

Fig. 12 Percentage increase of the fundamental period of an 8-storey and a 14-storey RC frame (Number of spans 6 - Masonry Wall Stiffness Et=2.25E+05 kN/m)

Table 5 Fundamental period of a six-span-8-storey and 14-storey fully infilled concrete frame for different span lengths

\begin{tabular}{|c|c|c|c|c|c|c|c|c|c|c|}
\hline \multicolumn{3}{|c|}{ Masonry Wall } & \multirow{2}{*}{\multicolumn{4}{|c|}{$\begin{array}{l}\text { 8-storey Frame } \\
\text { Span Length (m) }\end{array}$}} & \multirow{2}{*}{\multicolumn{4}{|c|}{$\begin{array}{l}\text { 14-storey Frame } \\
\text { Span Length (m) }\end{array}$}} \\
\hline \multirow{2}{*}{$\begin{array}{l}\text { Modulus of } \\
\text { Elasticity } E \\
\text { (MPa) }\end{array}$} & \multirow{2}{*}{$\begin{array}{l}\text { Thickness } t \\
\text { (m) }\end{array}$} & \multirow{2}{*}{$\begin{array}{c}\text { Stiffness } \\
E t\left(\times 10^{5}\right. \\
\mathrm{kN} / \mathrm{m})\end{array}$} & & & & & & & & \\
\hline & & & 3.0 & 4.5 & 6.0 & 7.5 & 3.0 & 4.5 & 6.0 & 7.5 \\
\hline- & - & - & 0.72 & 0.89 & 1.03 & 1.200 & 1.230 & 1.530 & 1.853 & 2.189 \\
\hline 1,500 & 0.15 & 2.25 & 0.458 & 0.502 & 0.537 & 0.588 & 0.780 & 0.851 & 0.941 & 1.035 \\
\hline 3,000 & 0.15 & 4.50 & 0.376 & 0.400 & 0.422 & 0.456 & 0.639 & 0.677 & 0.735 & 0.798 \\
\hline 3,000 & 0.25 & 7.50 & 0.319 & 0.334 & 0.349 & 0.375 & 0.542 & 0.564 & 0.606 & 0.654 \\
\hline 4,500 & 0.25 & 11.25 & 0.277 & 0.289 & 0.300 & 0.319 & 0.473 & 0.486 & 0.519 & 0.557 \\
\hline 10,000 & 0.15 & 15.00 & 0.251 & 0.260 & 0.268 & 0.285 & 0.427 & 0.438 & 0.465 & 0.497 \\
\hline 8,000 & 0.25 & 20.00 & 0.226 & 0.234 & 0.241 & 0.254 & 0.386 & 0.394 & 0.417 & 0.444 \\
\hline 10,000 & 0.25 & 25.00 & 0.209 & 0.216 & 0.222 & 0.233 & 0.356 & 0.363 & 0.384 & 0.407 \\
\hline
\end{tabular}




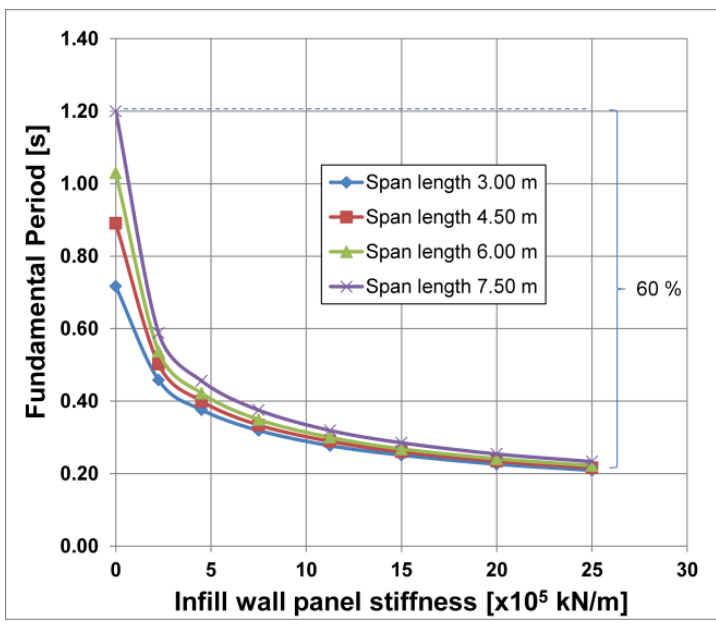

(a) 8-storey frame

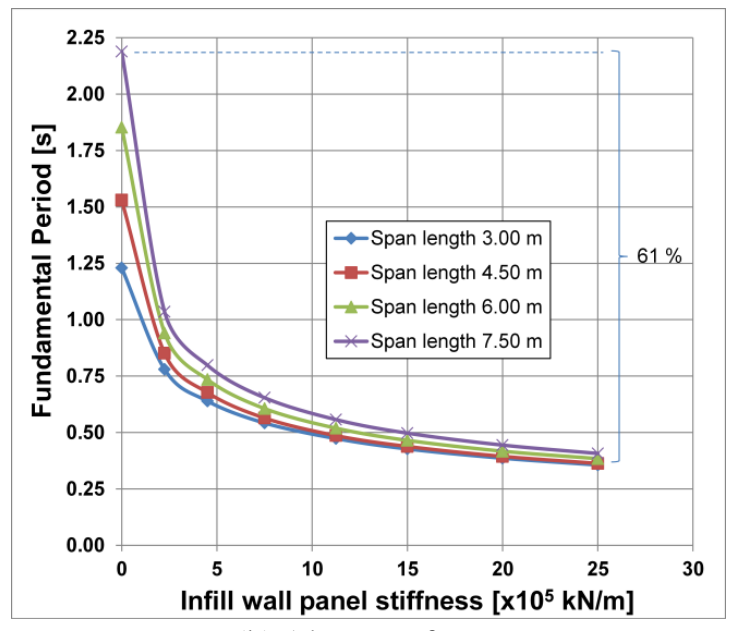

(b) 14-storey frame

Fig. 13 Influence of masonry stiffness on the fundamental period of an 8-storey and a 14-storey fully infilled RC frame (Number of spans 6)

\subsection{Influence of infill masonry panel stiffness on the fundamental period}

The mechanical characteristics of the masonry infill panels are shown in Table 5. The same Table and Fig. 13 show the determined fundamental period versus the infill masonry panel stiffness $E t$ ( $E$ : modulus of elasticity, $t$ : thickness of the masonry panel) for both the 8-storey and 14-storey infilled RC frames for six spans with lengths ranging from 3 to $7.5 \mathrm{~m}$. From Fig. 13, it can be seen that the period is highly sensitive to the infill wall panel stiffness. Infills act as diagonal bracing and resist lateral deflection. So, if the infill wall panel stiffness increases, the lateral deflection decreases and the fundamental period decreases. For both the 8-storey and 14storey RC frame (Fig. 13a and b), it can be seen that the influence of the span length on the fundamental period of the structure is smaller as the infill wall stiffness increases. The largest influence of the span length is for the bare frames. For infill wall stiffness equal to $25 \times 10^{5} \mathrm{kN} / \mathrm{m}$ it is apparent that the change in span length does not affect significantly the fundamental period of the frames. Finally, from Fig. 13, it can be seen that the fundamental period of both RC frames ( 8 and 14-storey) decreases by about $60 \%$ for a change in infill wall stiffness from each $2.25 \times 10^{5}$ to $25 \times 10^{5} \mathrm{kN} / \mathrm{m}$ with six spans and $7.5 \mathrm{~m}$ span length. We can conclude that the decrease of the fundamental period as a result of the influence of infill masonry panel stiffness is almost the same for the 8-storey and 14-storey RC frame.

\subsection{Influence of infill openings percentage on the fundamental period of infilled frames}

Sensitivity analysis has been carried out in order to investigate the influence of the infill opening. Both the 8-storey and the 14-storey RC frames have been analysed. Fig. 14 shows the influence of infill opening (in terms of infill opening percentage with respect to total area of masonry wall) on the fundamental period of an 8-storey and a 14-storey fully infilled RC frame with six spans and span length equal to $6 \mathrm{~m}$. The values of the fundamental period of these infilled frames with openings are shown in Table 6. From Fig. 14 and Table 6, it can be seen that as the 
Table 6 Fundamental Period of an 8-storey and a 14-storey partially infilled concrete frame

\begin{tabular}{|c|c|c|c|c|c|c|c|}
\hline \multirow[b]{2}{*}{ Case } & \multirow{2}{*}{$\begin{array}{c}\text { Masonry Wall } \\
\text { Stiffness } \\
\mathrm{Et} \\
{\left[\times 10^{5} \mathrm{kN} / \mathrm{m}\right]}\end{array}$} & \multicolumn{5}{|c|}{ Opening Percentage } & \multirow[b]{2}{*}{ Reduction [\%] } \\
\hline & & 0.00 & 25.00 & 50.00 & 75.00 & 100.00 & \\
\hline \multirow{8}{*}{ 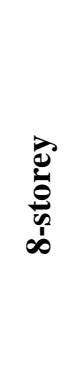 } & 2.25 & 0.537 & 0.790 & 0.944 & 1.030 & 1.030 & 47.86 \\
\hline & 4.50 & 0.422 & 0.672 & 0.870 & 1.018 & 1.030 & 59.03 \\
\hline & 7.50 & 0.349 & 0.580 & 0.800 & 1.004 & 1.030 & 66.12 \\
\hline & 11.25 & 0.300 & 0.509 & 0.735 & 0.988 & 1.030 & 70.87 \\
\hline & 15.00 & 0.268 & 0.462 & 0.662 & 0.974 & 1.030 & 73.98 \\
\hline & 20.00 & 0.241 & 0.417 & 0.635 & 0.956 & 1.030 & 76.60 \\
\hline & 25.00 & 0.222 & 0.385 & 0.596 & 0.939 & 1.030 & 78.45 \\
\hline & Reduction [\%] & 58.66 & 51.27 & 36.86 & 8.84 & 0.00 & \\
\hline \multirow{8}{*}{ 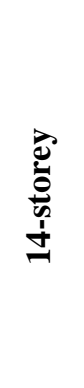 } & 2.25 & 0.941 & 1.405 & 1.692 & 1.855 & 1.853 & 49.22 \\
\hline & 4.50 & 0.735 & 1.186 & 1.553 & 1.833 & 1.853 & 60.33 \\
\hline & 7.50 & 0.606 & 1.019 & 1.420 & 1.806 & 1.853 & 67.30 \\
\hline & 11.25 & 0.519 & 0.891 & 1.300 & 1.775 & 1.853 & 71.99 \\
\hline & 15.00 & 0.465 & 0.806 & 1.210 & 1.747 & 1.853 & 74.91 \\
\hline & 20.00 & 0.417 & 0.726 & 1.118 & 1.713 & 1.853 & $\mathbf{7 7 . 5 0}$ \\
\hline & 25.00 & 0.384 & 0.669 & 1.046 & 1.682 & 1.853 & 79.28 \\
\hline & Reduction [\%] & 59.19 & 52.38 & 38.18 & 9.33 & 0.00 & \\
\hline
\end{tabular}

Note: Number of spans $=6$; Span length $=6.00 \mathrm{~m}$

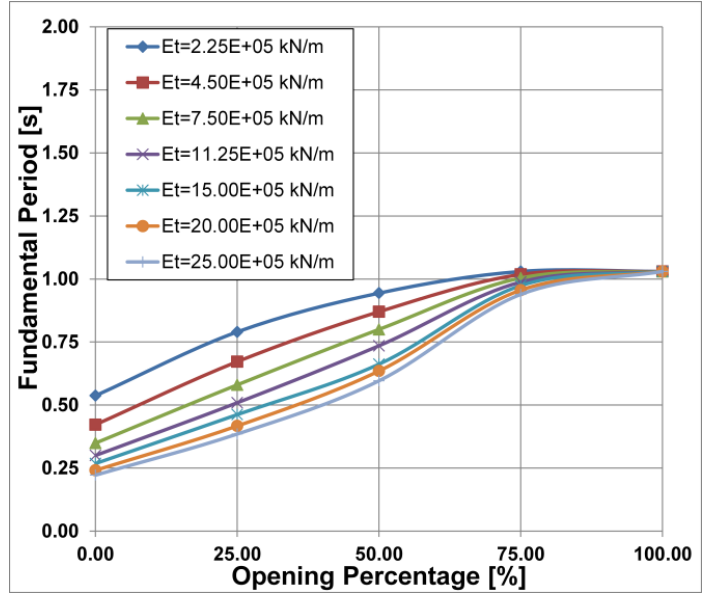

(a) 8-storey frame

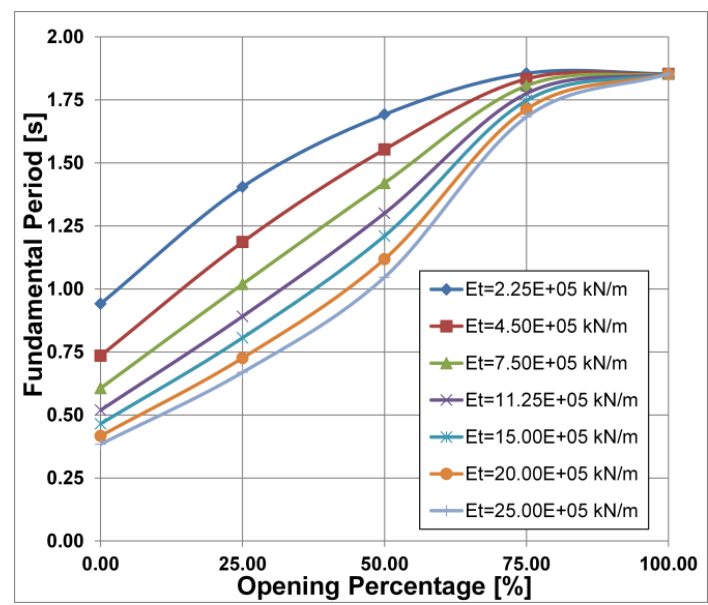

(b) 14-storey frame

Fig. 14 Influence of opening percentage on the fundamental period of an 8-storey and a 14-storey fully infilled RC frame (Number of spans 6; Span length=6.00 m)

infill opening percentage increases from full infill (i.e., no opening, $0 \%$ infill opening percentage) to $75-80 \%$ infill opening, the fundamental period increases almost linearly. However, when the 
infill opening percentage is ranging from $80 \%$ to $100 \%$ (i.e., bare frame), the opening does not affect the fundamental periods. This is due to the fact that when the opening is above $85 \%$, the mass and stiffness of the infill does not contribute to the fundamental period. Finally, for both frames with the same opening, the higher the masonry stiffness, the lower the fundamental period. For the 8-storey frame and for values of masonry infill wall stiffness $(\mathrm{Et})$ ranging from 2.25 to $25 \times 10^{5} \mathrm{kN} / \mathrm{m}$, the fundamental period ranges from $0.22 \mathrm{~s}$ (fully infilled) to $1.03 \mathrm{~s}$ (bare frame) while for the 14-storey frame it ranges from $0.38 \mathrm{~s}$ to $1.85 \mathrm{~s}$. The reduction of the fundamental period of the fully infilled frames with respect to bare frames is 78 and $79 \%$, respectively, for infill wall stiffness equal to $25 \times 10^{5} \mathrm{kN} / \mathrm{m}$.

\subsection{Influence of soft storey on the fundamental period}

In earthquake resistant design, irregular building configurations due to architectural features are a significant source of serious earthquake damage. The influence of the location of the soft storey irregularity (absence of infill walls) on the fundamental period of an 8-storey and a 14-storey RC frame with six spans is presented herein. According to ASCE/SEI 7-10 (2010), the soft storey irregularity (or flexible storey) is characterised as "Irregularity Type 1" and refers to the existence

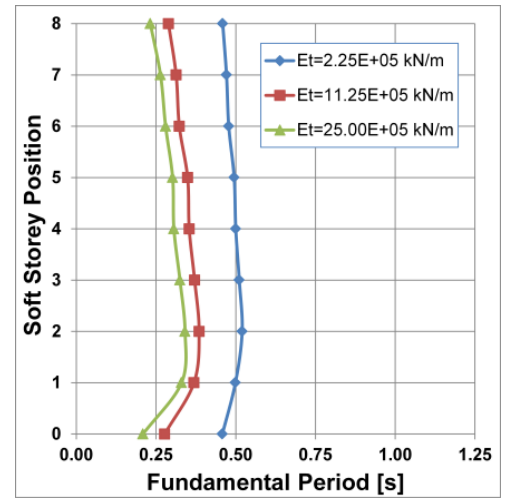

(a) 8-storey, Span length $=3.00 \mathrm{~m}$

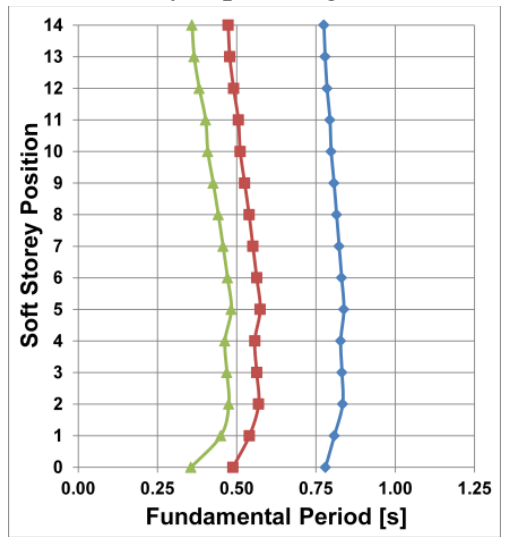

(d) 14-storey, Span length $=3.00 \mathrm{~m}$

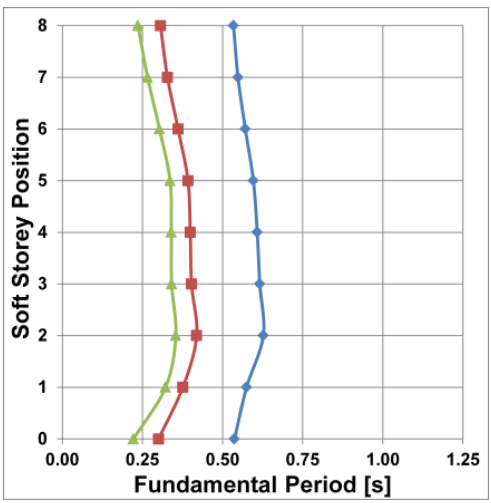

(b) 8-storey, Span length $=6.00 \mathrm{~m}$

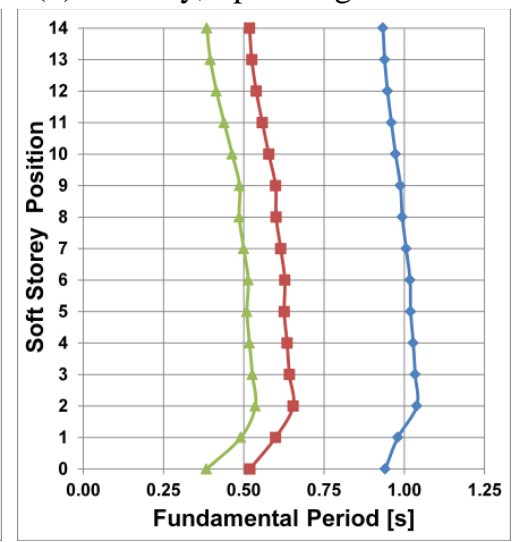

(e) 14-storey, Span length $=6.00 \mathrm{~m}$

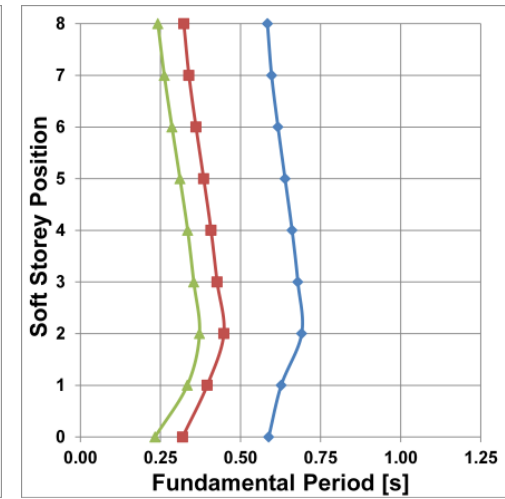

(c) 8-storey, Span length $=7.50 \mathrm{~m}$

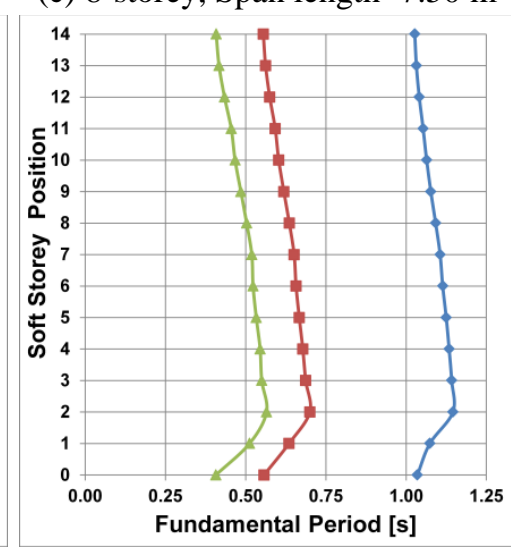

(f) 14-storey, Span length=7.50 m

Fig. 15 Influence of soft storey position on the fundamental period of an 8-storey and a 14-storey fully infilled RC frame (Number of spans 6) 
of a building floor that presents a significantly lower stiffness than the others. In particular, the location of the soft storey varied from the first floor (case of Pilotis) to the top floor. The masonry infill panel stiffness's were $2.25,11.25$ and $25 \times 10^{5} \mathrm{kN} / \mathrm{m}$, while the span lengths were $3.0,6.0$ and $7.5 \mathrm{~m}$. In total, 216 different cases were analysed. Fig. 15 shows the influence of soft storey position on the fundamental period of an 8-storey and a 14-storey fully infilled RC frame with six spans. It can be seen that, for all frames, the higher fundamental period occurs when the soft storey is at the second floor. In particular for the 14-storey frame with span length equal to $3 \mathrm{~m}$, the fundamental period is higher when the soft storey is located at either the second or the fifth floor (Fig. 15d). The fundamental period depends on the location of the soft storey across the height of the building. Lower values of the period result when the soft storey is at the top floor, closer to the value of the fully infilled frame. Higher values of the period are evaluated for a soft storey at lower storeys but not at the first storey. The difference between the minimum and maximum fundamental period for different positions of the soft storey is $7 \%$ for the 14-storey frame with masonry wall stiffness $2.25 \times 10^{5} \mathrm{kN} / \mathrm{m}$ and $3.0 \mathrm{~m}$ span length and $28 \%$ for the 14 -storey frame with masonry wall stiffness $25 \times 10^{5} \mathrm{kN} / \mathrm{m}$ and $7.5 \mathrm{~m}$ span length. These differences become $12 \%$ and $35 \%$, respectively, for the 8 -storey frame. This effect becomes smaller for lower values of stiffness.

\subsection{Influence of soil-structure interaction on the fundamental period}

Fig. 16 shows the influence of soil-structure interaction on the fundamental period of an 8storey and a 14-storey fully infilled RC frame with six spans and span length equal to $6 \mathrm{~m}$. The frames have been analysed taking into account the flexibility of the soil, as described in 4.4. As it was expected, the soil-structure interaction strongly affects the fundamental period. In general, the value of the fundamental period is higher when the soil is more flexible.

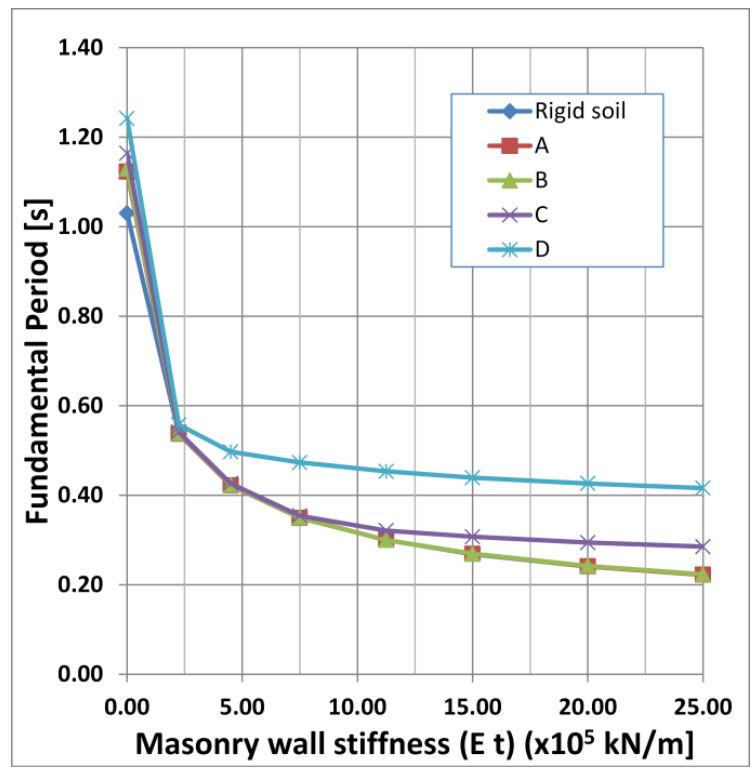

(a) 8-storey frame

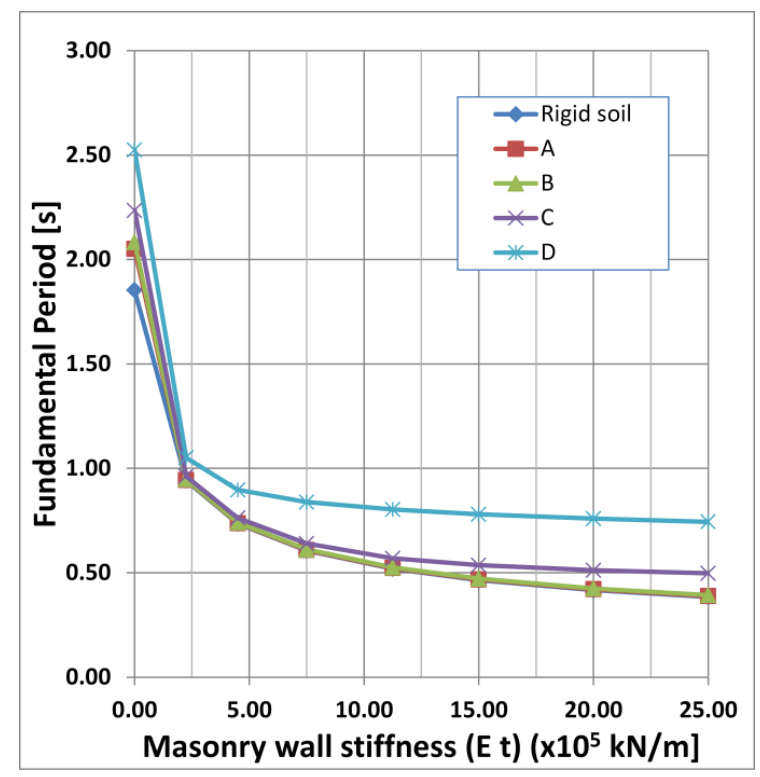

(b) 14-storey frame

Fig. 16 Influence of soil-structure interaction on the fundamental period of an 8-storey and a 14-storey bare and fully infilled RC frame (Number of spans 6) 
From Fig. 16 it can be seen that fundamental period increases by $10 \%$ to $36 \%$ for the case of the 14-storey bare frame, if soil-structure interaction is taken into account. Infilled frames on rigid soil and soil types A and B have similar fundamental periods. Soil type $\mathrm{C}$ results to a higher value of the fundamental period (by $30 \%$ compared to rigid soil for masonry wall stiffness $25 \times 10^{5} \mathrm{kN} / \mathrm{m}$ of the 14-storey infilled frame) while soil type D results to a higher value by $94 \%$ compared to rigid soil for masonry wall stiffness $25 \times 10^{5} \mathrm{kN} / \mathrm{m}$ of the 14-storey infilled frame. Similar results are taken from the 8-storey frame.

The higher the infill wall stiffness, the higher the influence of soil-structure interaction. Soilstructure interaction strongly influence the bare frames too, while the smaller influence is observed for infilled frames with masonry wall stiffness $2.25 \times 10^{5} \mathrm{kN} / \mathrm{m}$.

\section{Conclusions}

Despite the fact that the fundamental period is one of the most critical parameters affecting the seismic design of structures, the available methods for its estimation do not take into account crucial parameters and very often conflict with each other, thus making their use uncertain. In the present paper, a sensitivity analysis has been undertaken to investigate the parameters that affecting the fundamental period of Infilled RC Frame Structures. More specifically, the parameters investigated include: a) the number of spans; b) the influence of span length in the direction of motion; c) the influence of infill stiffness in the structure; d) the infill panel opening percentage; e) the soft storey position and $\mathrm{f}$ ) the soil type.

From the present study the following conclusions can be drawn:

- The number of spans does not have a significant effect on the period;

- Increasing the span length increases the fundamental period of the infilled RC framed building. In particular, a linear relationship between the period and the span length has been observed;

- An increase of the infill wall panel stiffness from $2.25 \times 10^{5}$ to $25 \times 10^{5} \mathrm{kN} / \mathrm{m}$ reduces the fundamental period by approximately $60 \%$;

- As the opening increases from full infill to $80 \%$ opening, the fundamental period of the structure increases almost linearly. However, when the opening percentage is $80 \%$ and above, the increase of the opening does not affect the fundamental period of the structure since it is almost the same with the period of the bare structure;

- For both the 8-storey and 14-storey frames with the same opening, the higher the masonry stiffness, the lower the fundamental period;

- The location of the soft storey in the structure and the length of the span in the direction of motion significantly affect the fundamental period of the structure. The fundamental period is higher when the soft storey is located at the second floor of the building;

- The soil-structure interaction strongly affects the fundamental period. The fundamental period is higher for more flexible soil types as the soil type $\mathrm{C}$ according to $\mathrm{EC} 8$, which corresponds to medium dense sand $(k=1,500,000 \mathrm{kN} / \mathrm{m})$ and the soil type $\mathrm{D}$, which corresponds to loose to medium cohesionless soil $(k=450,000 \mathrm{kN} / \mathrm{m})$. Furthermore, the influence of soil-structure interaction is higher when the infill wall stiffness is higher.

As delineated by the authors of this paper, a more reliable equation (with respect to the already available ones) can be developed for the estimation of the fundamental period. The detailed exposition of such an equation will be presented in a companion paper after having first 
investigated additional cases of storey numbers; such an investigation is a prerequisite for the successful implementation of nonlinear regression analysis for the determination of the fundamental period.

\section{References}

AFPS-90 (1990), Recommendations for the redaction of rules relative to the structures and installation built in regions prone to earthquakes, France Association of Earthquake Engineering, Paris, France.

Agrawal, R. and Hora, M.S. (2012), "Nonlinear interaction behaviour of infilled frame-isolated footings-soil system subjected to seismic loading”, Struct. Eng. Mech., 44(1), 85-107.

Algerian Seismic Code (1988), Algerian Earthquake Resistance Regulations, Ministry of Town-planning and Construction, Algiers, Algeria.

Al-Nimry, H., Resheidat, M. and Al-Jamal, M. (2014), “Ambient vibration testing of low and medium rise infilled RC frame buildings in Jordan”, Soil Dyn. Earthq. Eng., 59, 21-29.

Amanat, K.M. and Hoque, E. (2006), "A rationale for determining the natural period of RC building frames having infill”, Eng. Struct., 28(4), 495-502.

American Society of Civil Engineers (ASCE) (2010), Minimum design loads for buildings and other structures: ASCE Standard ASCE/SEI 7-10, Reston, Virginia.

Applied Technology Council (ATC) (1978), "Tentative Provision for the development of seismic regulations for buildings", Report No. ATC3-06, Applied Technology Council, California.

Arslan, M.E. and Durmus, A. (2014), "Modal parameter identification of in-filled RC frames with low strength concrete using ambient vibration”, Struct. Eng. Mech., 50(2), 137-149.

Asteris, P.G. (2003), "Lateral stiffness of brick masonry infilled plane frames", J. Struct. Eng., ASCE, 129(8), 1071-1079.

Asteris, P.G. (2005), "Closure to "Lateral stiffness of brick masonry infilled plane frames", Ed. P.G. Asteris, J. Struct. Eng., ASCE, 131(3), 523-524.

Asteris, P.G. (2008), "Finite element micro-modeling of infilled frames", Electro. J. Struct. Eng., 8(8), 1-11.

Asteris, P.G., Antoniou, S.T., Sophianopoulos, D.S. and Chrysostomou, C.Z. (2011), "Mathematical macromodeling of infilled frames: State of the art", J. Struct. Eng., ASCE, 137(12), 1508-1517.

Asteris, P.G., Cotsovos, D.M., Chrysostomou, C.Z., Mohebkhah, A. and Al-Chaar, G.K. (2013). "Mathematical micromodeling of infilled frames: State of the art", Eng. Struct., 56, 1905-1921.

Bureau of Indian Standards (2002), IS-1893, Indian Standard Criteria for Earthquake Resistant Design of Structures-Part 1: General Provisions and Buildings, Fifth Revision, New Delhi, India.

Campione, G., Cavaleri, L., Macaluso, G., Amato, G. and Di Trapani, F. (2014), "Evaluation of infilled frames: an updated in-plane-stiffness macro-model considering the effects of vertical loads", Bull. Earthq. Eng., 13(8), 2265-2281.

Cavaleri, L. and Di Trapani, F. (2014), "Cyclic response of masonry infilled RC frames: Experimental results and simplified modelling”, Soil Dyn. Earthq. Eng., 65, 224-242.

Cavaleri, L. and Di Trapani, F. (2015), "Prediction of the additional shear action on frame members due to infills", Bull. Earthq. Eng., 13(5), 1425-1454.

Cavaleri, L. and Papia, M. (2003) "A new dynamic identification technique: application to the evaluation of the equivalent strut for infilled frames", Eng. Struct., 25(7), 889-901.

Cavaleri, L. and Papia, M. (2014), "An output-only stochastic parametric approach for the identification of linear and nonlinear structures under random base excitations: Advances and comparisons", Prob. Eng. Mech., 35, 11-21.

Cavaleri, L., Fossetti, M. and Papia, M. (2005), "Infilled frames: developments in the evaluation of cyclic behaviour under lateral loads", Struct. Eng. Mech., 21(4), 469-494.

Chopra, A.K. and Goel, R.K. (2000), "Building period formulas for estimating seismic displacements", Earthq. Spectra, 16(2), 533-536. 
Chrysostomou, C.Z. (1991), "Effects of degrading infill walls on the nonlinear seismic response of twodimensional steel frames", Ph.D. Dissertation, Cornell University, Ithaca, NY.

Chrysostomou, C.Z. and Asteris, P.G. (2012), "On the in-plane properties and capacities of infilled frames", Eng. Struct., 41, 385-402.

Chrysostomou, C.Z., Gergely, P. and Abel, J.F. (2002), "A six-strut model for nonlinear dynamic analysis of steel infilled frames", Int. J. Struct. Stabil. Dyn., 2(3), 335-353.

Crisafulli, F.J. (1997), "Seismic behaviour of reinforced concrete structures with masonry infills", Ph.D. Dissertation, University of Canterbury, New Zealand.

Crowley, H. and Pinho, R. (2004), "Period-height relationship for existing European reinforced concrete buildings", J. Earthq. Eng., 8(1), 93-119.

Crowley, H. and Pinho, R. (2006), "Simplified equations for estimating the period of vibration of existing buildings", Proceedings of the First European Conference on Earthquake Engineering and Seismology, Geneva.

Crowley, H. and Pinho, R. (2010), "Revisiting Eurocode 8 formulae for periods of vibration and their employment in linear seismic analysis", Earthq. Eng. Struct. Dyn., 39(2), 223-235.

D.M. LL. PP. (2008), 14 Gennaio, Nuove norme tecniche per le costruzioni, Italy.

Dhanasekar, M. and Page, A.W. (1986), "Influence of brick masonry infill properties on the behaviour of infilled frames", Proceedings of the Institution of Civil Engineers, London.

Ditommaso, R., Vona, M., Gallipoli, M.R. and Mucciarelli, M. (2013), "Evaluation and considerations about fundamental periods of damaged reinforced concrete buildings", Natl. Haz. Earth Syst. Sci., 13(7), 19031912.

E.A.K. (2003), Greek Earthquake Resistant Design Code, Earthquake Design and Protection Organization (OASP) and Technical Chamber of Greece (TEE), Athens.

Egyptian Seismic Code (1988), Regulations for Earthquake Resistant Design of Buildings in Egypt, Egyptian Society for Earthquake Engineering, Cairo, Egypt.

Eleftheriadou, A.K. and Karabinis, A.I. (2013), "Correlation of structural seismic damage with fundamental period of RC buildings", Open J. Civ. Eng., 3(01), 45-67.

Erdolen, A. and Dorana, B. (2012), "Interval finite element analysis of masonry-infilled walls", Struct. Eng. Mech., 44(1), 73-84.

European Committee for Standardization CEN (2004), Eurocode 8: Design of Structures for Earthquake Resistance - Part 1: General Rules, Seismic Actions and Rules for Buildings, EuropeanStandard EN 1998$1: 2004$

FEMA-274 (1997), NEHRP Commentary on the Guidelines for the Seismic Rehabilitation of Buildings, Washington (DC), Federal Emergency Management Agency.

FEMA-306 (1998), Evaluation of earthquake damaged concrete and masonry wall buildings: basic procedures manual, Washington (DC), Federal Emergency Management Agency.

FEMA-356 (2000), Prestandard and commentary for the Seismic Rehabilitation of Buildings, Washington (DC), Federal Emergency Management Agency.

FEMA-450 (2003), NEHRP recommended provisions for seismic regulations for new buildings and other structures, Part 1: Provisions, Washington (DC), Federal Emergency Management Agency.

Goel, R.K. and Chopra, A.K (1997), "Period formulas for moment-resisting frame buildings", J. Struct. Eng., ASCE, 123(11), 1454-1461.

Guler, K., Yuksel, E. and Kocak, A. (2008), "Estimation of the fundamental vibration period of existing RC buildings in Turkey utilizing ambient vibration records", J. Earthq. Eng., 12(S2), 140-150.

Hatzigeorgiou, G.D. and Kanapitsas, G. (2013), "Evaluation of fundamental period of low-rise and mid-rise reinforced concrete buildings", Earthq. Eng. Struct. Dyn., 42(11), 1599-1616.

Hetenyi, M. (1946), "Beams on elastic foundations", University of Michigan Press, Ann Arbor.

Holmes, M. (1961), "Steel frames with brickwork and concrete infilling", Proceedings of the Institution of Civil Engineers, London.

Hong, L.L. and Hwang, W.L. (2000), "Empirical formula for fundamental vibration periods of reinforced concrete buildings in Taiwan”, Earthq. Eng. Struct. Dyn., 29(3), 326-333. 
Hora, M. (2006), "Nonlinear interaction analysis of infilled building frame-soil system", J. Struct. Eng. (Madras), 33(4), 309-318.

Internal Conference of Building Officials (1997), Uniform Building Code, California, Wilier.

Israel IC-413 (1994), SI 413 Design provision for Earthquake Resistant of structures, Standard Institute of Israel 1988.

Jordanian National Building Council (2005), Jordanian National Building Code for Earthquake-Resistant Buildings, Amman, Jordan.

Kakaletsis, D.J. and Karayannis, C.G. (2009), "Experimental investigation of infilled reinforced concrete frames with openings", ACI Struct. J., 106(2), 132-141.

Kose, M.M. (2009), "Parameters affecting the fundamental period of RC buildings with infill walls", Eng. Struct., 31(1), 93-102.

Kose, M.M. and Kayadelen, C. (2013), "Effects of infill walls on RC buildings under time history loading using genetic programming and neuro-fuzzy", Struct. Eng. Mech., 47(3), 401-419.

LH logismiki (2013), FESPA 10 for windows, v.5.4.0.100. Athens, Greece.

Mainstone, R.J. (1971), "On the stiffnesses and strengths of infilled frames”, Proceedings of the Institution of Civil Engineers, London.

Mainstone, R.J. (1974), "Supplementary note on the stiffness and strengths of infilled frames", Current Paper CP 13/74, Building Research Station, Garston, Watford, U.K.

Mainstone, R.J. and Weeks, G.A. (1970), "The influence of bounding frame on the racking stiffness and strength of brick walls", Proceedings of the 2nd International Brick Masonry Conference, Building Research Establishment, Watford, England.

Mander, J.B., Priestley, M.J.N. and Park, R. (1988), "Theoretical stress-strain model for confined concrete", J. Struct. Eng., ASCE, 114(8), 1804-1826.

Martinez-Rueda, J.E. and Elnashai, A.S. (1997), "Confined concrete model under cyclic load", Mater. Struct., 30(3), 139-147.

Massumi, A. and Moshtagh, E. (2010), "A new damage index for RC buildings based on variations of nonlinear fundamental period”, Struct. Des. Tall Spec. Build., 22(1), 50-61.

Mehrabi, A.B., Shing, P.B., Schuller, M. and Noland, J. (1966), "Experimental evaluation of masonryinfilled RC frames", J. Struct. Eng., ASCE, 122(3), 228-237.

Menegotto, M. and Pinto, P.E. (1973), "Method of analysis for cyclically loaded R.C. plane frames including changes in geometry and non-elastic behaviour of elements under combined normal force and bending", Symposium on the Resistance and Ultimate Deformability of Structures Acted on by Well Defined Repeated Loads, International Association for Bridge and Structural Engineering, Zurich, Switzerland.

Misir, I.S., Ozcelik, O., Girgin, S.C. and Kahraman, S. (2012), "Experimental work on seismic behavior of various types of masonry infilled RC frames", Struct. Eng. Mech., 44(6), 763-774.

Moghaddam, H.A. (2004), "Lateral load behavior of masonry infilled steel frames with repair and retrofit", J. Struct. Eng., ASCE, 130(1), 56-63.

Moghaddam, H.A. and Dowling, P.J. (1987), "The state of the art in infilled frames", ESEE Research Report No. 87-2, Imperial College of Science and Technology, Civil Engineering Department, London, UK.

National Research Council (1995), The National Building Code (NBC), Canada.

New Zealand Society of Earthquake Engineering (NZSEE) (2006), Assessment and improvement of the structural performance of buildings in earthquakes, Recommendations of a NZSEE Study Group on Earthquake Risk Buildings.

NSCP (1992), National Structural Code of Philippines, Vol. 1, Fourth Edition, The Board of Civil Engineering of the Professional Regulation Commission, Manila, Philippines.

NSR-84 (1984), Colombian Standards for Seismic Resistant Design and Construction, Bogota, Colombia.

NSR-98 (1998), Colombian Standards for Seismic Resistant Design and Construction, Bogota, Colombia.

Page, A.W., Kleeman, P.W. and Dhanasekar, M. (1985), "An in-plane finite element model for brick masonry”, Proceedings of a session held in conjunction with Structures Congress'85, Chicago.

Papia, M., Cavaleri, L. and Fossetti, M. (2003), "Infilled frames: developments in the evaluation of the 
stiffening effect of infills", Struct. Eng. Mech., 16(6), 675-693.

Pinto, A., Verzeletti, G., Molina, J., Varum, H., Pinho, R. and Coelho, E. (2002), "Pseudo-dynamic tests on non-seismic resisting RC frames (bare and selective retrofit frames)", Joint Research Centre (JRC), Ispra, Italy.

Polyakov, S.V. (1960), "On the interaction between masonry filler walls and enclosing frame when loading in the plane of the wall", Translation in earthquake engineering, Earthquake Engineering Research Institute, San Francisco.

Saneinejad, A. and Hobbs, B. (1995), "Inelastic design of infilled frames", J. Struct. Eng., ASCE, 121(4), 634-650.

Seismic Code of Costa Rica (1986), Federal College of Engineers and Architects of Costa Rica, Department of Design, Ministry of Construction.

SeismoSoft (2013), "SeismoStruct - A computer program for static and dynamic nonlinear analysis of framed structures" [online], Seismosoft Ltd., Pavia, Italy, v.6.5.200.

Smith, B.S. (1962), "Lateral stiffness of infilled frames", J. Struct. Div., ASCE, 88(ST6), 183-199.

Smith, B.S. (1966), "Behavior of square infilled frames", J. Struct. Div., ASCE, 92(ST1), 381-403.

Smyrou, E., Blandon, C., Antoniou, S., Pinho, R. and Crisafulli, F. (2011). "Implementation and verification of a masonry panel model for nonlinear dynamic analysis of infilled RC frames", Bull. Earthq. Eng., 9(5), 1519-1534.

Thomas, F.G. (1953), “The strength of brickwork”, Struct. Eng., 31(2), 35-46.

Venezuelan Seismic Code (1988), Regulations for Earthquake Resistant Buildings, Comision De Normas Industriales, Covenin, Caracas, Venezuela.

Wood, R.H. (1959), "Discussion on the Stability of tall buildings", Proceedings of the Institution of Civil Engineers, 12(4), 517-518.

$C C$ 